\title{
Nutritional Management of Diabetes Mellitus: An appraisal of the role of Medicinal plants
}

\author{
Dauda Muhammed ${ }^{1}$, Yetunde H. Adebiyi ${ }^{2}$ Bernard O. Odey ${ }^{3}$, Jonathan Ibrahim $^{4}$ Opeyemi N. \\ Hassan $^{5}$, Peter I Ugwunnaji ${ }^{6}$, Eustace B. Berinyuy ${ }^{7 *}$ \\ ${ }^{1}$ Southern Guinea Research Station-Forestry Research Institute of Nigeria, Mokwa, Niger State, Nigeria \\ ${ }^{2}$ Department of Biochemistry, Federal University of Technology Minna, Nigeria. \\ ${ }^{3}$ Trial Afforestation Research Station, Forestry Research Institute of Nigeria (FRIN), Afaka-Kaduna State, Nigeria. \\ ${ }^{4}$ Gombe State College of Health Science and Technology, Kaltungo, Nigeria \\ ${ }^{5}$ Centre International Universitaire Des Meilleurs (C.I.U.M), Bestower International University Seme-Podji-Republique Du Benin. \\ ${ }^{6}$ Department of Chemistry, Michael Okpara University of Agriculture, Umudike, P.M.B 7267, Umuahia, Abia State, Nigeria. \\ ${ }^{7}$ Faculty of Medicine and Biomedical Science, University of Yaounde 1, Yaounde, Cameroon.
}

Received: 22 December 2020, Revised: 26 February 2021, Published: 29 March 2021

OPEN ACCESS

\section{Summary}

Citations: Muhammed D, Adebiyi YH, Odey BO, Ibrahim J, Hassan ON, Ugwunnaji PI, and Berinyuy E.B. (2021). Nutritional Management of Diabetes Mellitus: An appraisal of the role of Medicinal plants. AROC in Natural Product Research. 01(01), 001-027

Corresponding author* Dr. Eustace B. Berinyuy Faculty of Medicine and Biomedical Science, University of Yaoundé 1, Yaounde, Cameroon

\begin{abstract}
Diabetes mellitus is a heterogeneous metabolic syndrome characterized by chronic hyperglycemia with partial or total lack of insulin secretion and insulin resistance. The most common symptoms are polydipsia, polyuria, blurred vision, slow healing sore, nerve damage. Diabetes, being a metabolic, endocrine disorder is directly connected to carbohydrates, lipid, and protein metabolism. As a result, nutrition therapy forms an integral part of diabetes management. Daily caloric intake of $50 \%-55 \%$ carbohydrates is recommended. Carbohydrate with low glycaemic index is preferred to those with high glycaemic index. Nonnutritive sweeteners are also encouraged for people with diabetes to add increased variety to their food choices. The protein requirement for persons with diabetes is not different from the general population, 15-20\% of total caloric intake. Both soluble and insoluble fibers are encouraged in amounts similar to the recommendations for the general population (20-35 g). Fibers are useful as they prolong gastric emptying, prevent constipation, lower serum cholesterol level, and reduce nutrients diffusion rates, thus reducing blood glucose response. A low-fat diet is advisable for diabetics in order to reach and maintain good weight and health. As part of a healthy diet, $30 \%$ of daily calories should come from fats, and of these less than $10 \%$ should be saturated fat, less than $10 \%$ polyunsaturated fat and 10 $15 \%$ monounsaturated fat. As the general population, people with diabetes have no need for vitamin and mineral supplementation when the dietary intake is adequate. Despite much research on nutritional factors in the etiology and management of diabetes, the risk associated with several individual nutrients is not entirely clear. In order to achieve maximum benefit from nutritional interventions in the management of diabetes changes in government policies and legislation will be needed in addition to individual and community-based programs.
\end{abstract}

Keywords: Diabetes mellitus, Nutritional management, Medicinal plant, hyperglycemia

\subsection{Introduction}

Food supply and intake is very important to the body regardless of age, sex, religion, occupation or season. Food must be taken with consciousness for well-being of the body. Too much or two little food intake may cause serious damage to the body system. This can result to various diseases - among which is diabetes (Belinda, 2004).
Diabetes mellitus is a combination of heterogeneous disorders commonly present with episodes of hyperglycaemia and glucose intolerance, as a result of lack of insulin, defective insulin action, or both (Sicree et al., 2006). Such complications arise due to derangements in the regulatory systems for storage and mobilization of metabolic fuels, including the catabolism and anabolism of carbohydrates, lipids and proteins emanating from 
defective insulin secretion, insulin action, or both (Votey and Peters, 2004). In addition to insulin, aging, over weight and several other hormones affect blood glucose level thereby preventing glucose from entering the cells (Clavel, 2005). This leads to hyperglycaemia, which may result in acute and chronic complications such as diabetic ketoacidosis, coronary artery disease, cerebrovascular disease, kidney and eye diseases, disorders of the nerves and others (Iwueze, 2007).

Classification of diabetes mellitus is based on its aetiology and clinical presentation. As such, there are four types or classes of diabetes mellitus viz; type 1 diabetes, type 2 diabetes, gestational diabetes, and other specific types (Sicree et al., 2006). Type 1 diabetes is said to account for only a minority of the total burden of diabetes in a population, although it is the major type of the diabetes in younger age groups developed countries (Sicree et al., 2006). Type 2 diabetes accounts for 85 to $95 \%$ of all diabetes in developed countries. It is intimately associated with improper utilisation of insulin by target cells and tissues. It is currently a common and serious health concern globally (Votey and Peters, 2004).

The dietary management of diabetes mellitus is a complement of lifestyle management. It has a positive effect on long term health and quality of life. Dietary management aims at optimal metabolic control by establishing a balance between food intake, physical activity, and medication to avoid complications. In type 2 diabetes, the dietary objective is for improved blood glucose and lipid levels and weight loss as appropriate (Piero, 2006). Because Diabetes Mellitus is a disease directly related to carbohydrate, lipid, and protein metabolism, nutrition has always had an integral role in its management. The contemporary term used to describe the dietary prescriptions is medical nutrition therapy (MNT) (American Diabeties Association, 2002). Before the advent of insulin therapy in the early 20th century, MNT was the only form of therapy for diabetes mellitus (Piero, 2006). The focus of nutritional recommendations at the turn of the last century was on type 1 diabetes mellitus: on control of the severe hyperglycaemia to which these patients are vulnerable as well as on prevention of what was then, before the advent of insulin therapy, commonly a mortal episode of ketoacidosis (Piero, 2006).

Medicinal plants play a significant role in the treatment of diabetes mellitus which is a serious metabolic disorder.
Traditional plants are reported to have significant antidiabetic properties with no harmful side effects. They are rich sources of anti-diabetic compounds such as flavonoids, alkaloids, phenolic and tannins that improve the efficiency of pancreatic tissues by increasing the insulin secretion or decreasing the intestinal absorption of glucose (Bindu \& Narendhirakannan, 2019; Kooti et al. 2016)

\subsection{Biochemical Background of Diabetes Mellitus}

Diabetes mellitus is a group of diseases characterised by high levels of glucose in the blood resulting from defects in insulin production (insulin deficiency), insulin action (insulin resistance), or both. Insulin is a hormone produced by the pancreas. After eating, the carbohydrates are metabolised to glucose that enters the bloodstream. Insulin is needed for the uptake glucose into the liver where it is used for energy, and excesses are stored in the liver and fat cells. Insufficient amounts of working insulin cause blood sugar levels to rise and large amounts of glucose are excreted in the urine (Kibiti, 2006).

A regular energy source is a prerequisite for every cell to function in the human body. Glucose is the body's primary energy source, which circulates in the blood as a mobilisable fuel source for cells (Njagi, 2006). Insulin is a pancreatic hormone responsible for blood glucose level regulation. The hormone binds to its receptor sites on peripheral side of the cell membranes. It affords entry of glucose into respiring cells and tissues via requisite channels. Insulin stimulates catabolism of glucose into pyruvate through glycolysis. It also regulates glycogenesis and lipogenesis from excessive cytosolic glucose and acetylCoA respectively. These metabolic events are antagonistic to metabolic events triggered by the hormone glucagon. When glucose levels are at or below threshold, glucose stays in the blood instead of entering the cells (Belinda, 2004).

The body attempts to arrest hyperglycaemia, by drawing water out of the cells and into the bloodstream. The excess sugar is excreted in the urine. This is why diabetes present with constant thirst, drinking large amounts of water, and polyuria as the cells tries to get rid of the extra glucose. This subsequently leads to glucosuria (Piero, 2006).

As hyperglycaemia prolongs, the body cells are devoid of glucose due to the lack of insulin. This forces the cells to seek alternative mobilisable energy sources. In this regard,

Citations: Muhammed D, Adebiyi YH, Odey BO, Ibrahim J, Hassan ON, Ugwunnaji PI, and Berinyuy E.B. (2021). Nutritional Management of Diabetes Mellitus: An appraisal of the role of Medicinal plants. AROC in Natural Product Research. 01(01), 001-027 
the cells turn to fatty acids stored in adipose tissue. The fats are not fuel sources for the red blood cells, kidney cortex and the brain. The red blood cells lack mitochondria in which beta-oxidation pathway occurs. The fatty acids cannot pass the blood-brain barrier. To avail energy to such cells and tissues, the acetyl-CoA arising from catabolism of fatty acids is diverted to ketogenesis to generate ketone bodies, which can serve as alternative fuel sources for such cells and tissues. These ketone bodies are also passed in the urine, thereby leading to ketonuria, which characterises diabetes mellitus. Buildup of ketone bodies in the blood produces ketosis. Ketone bodies are acidic in nature and therefore, their build up in blood lowers blood $\mathrm{pH}$, leading to acidosis. A combination of ketosis and acidosis lead to a condition called ketoacidosis. If left untreated, ketoacidosis leads to coma and death (Belinda, 2004).

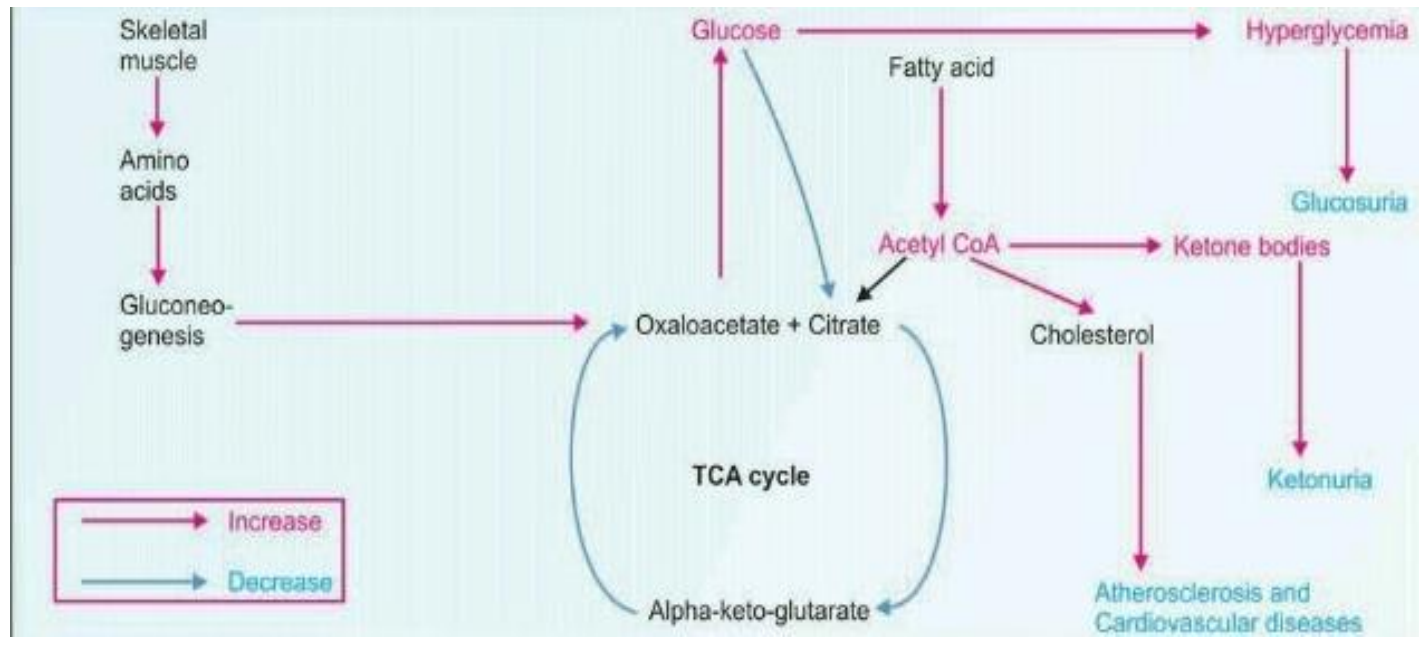

Figure 1: Metabolic derangement of diabetes mellitus

Source: Vasudevan et al., 2011.

\subsection{Pathophysiology of Diabetes Mellitus}

The pathophysiology of diabetes mellitus is related to the hormone, insulin secreted by beta cells of the pancreas. This hormone is responsible for maintaining glucose level in the blood. However, in a diabetic person, due to abnormal insulin metabolism, the body cells and tissue do not make use of glucose from the blood resulting in an elevated level of blood glucose or hyperglycaemia (Njagi, 2006).

In diabetes, blood glucose surges after a meal and remains above normal levels because insulin is either inadequate or ineffective. Thus blood glucose is central to diabetes. There are two main types of diabetes- Type 1 Diabetes and Type 2 Diabetes. In type 1 diabetes, this is an autoimmune disorder that is less common and the pancreas fails to make insulin.
Type1 diabetes occurs commonly in childhood and adolescence, but can occur at any age (Piero et al., 2014)

In Type I diabetes, the pancreas cannot synthesize enough amount of insulin as require by the body. The pathophysiology of this type of diabetes mellitus suggests that it is an auto immune disease in which the body's own immune system generates secretion of substance that attacks the beta cells of the pancreas. Some researchers suggest that in genetically susceptible people, certain viruses activate the immune system to attack and destroy cells in the pancreas as if they were foreign cells (Piero et al., 2014). In type 2 diabetes, the more common type of diabetes whereby the cells fail to respond to insulin; this condition tend to occur as a consequence of obesity it usually develops in people over 40 years old (Njagi, 2006).

Another type of diabetes which is less common is gestational diabetes which develops in some women during pregnancy (Piero et al., 2014). 


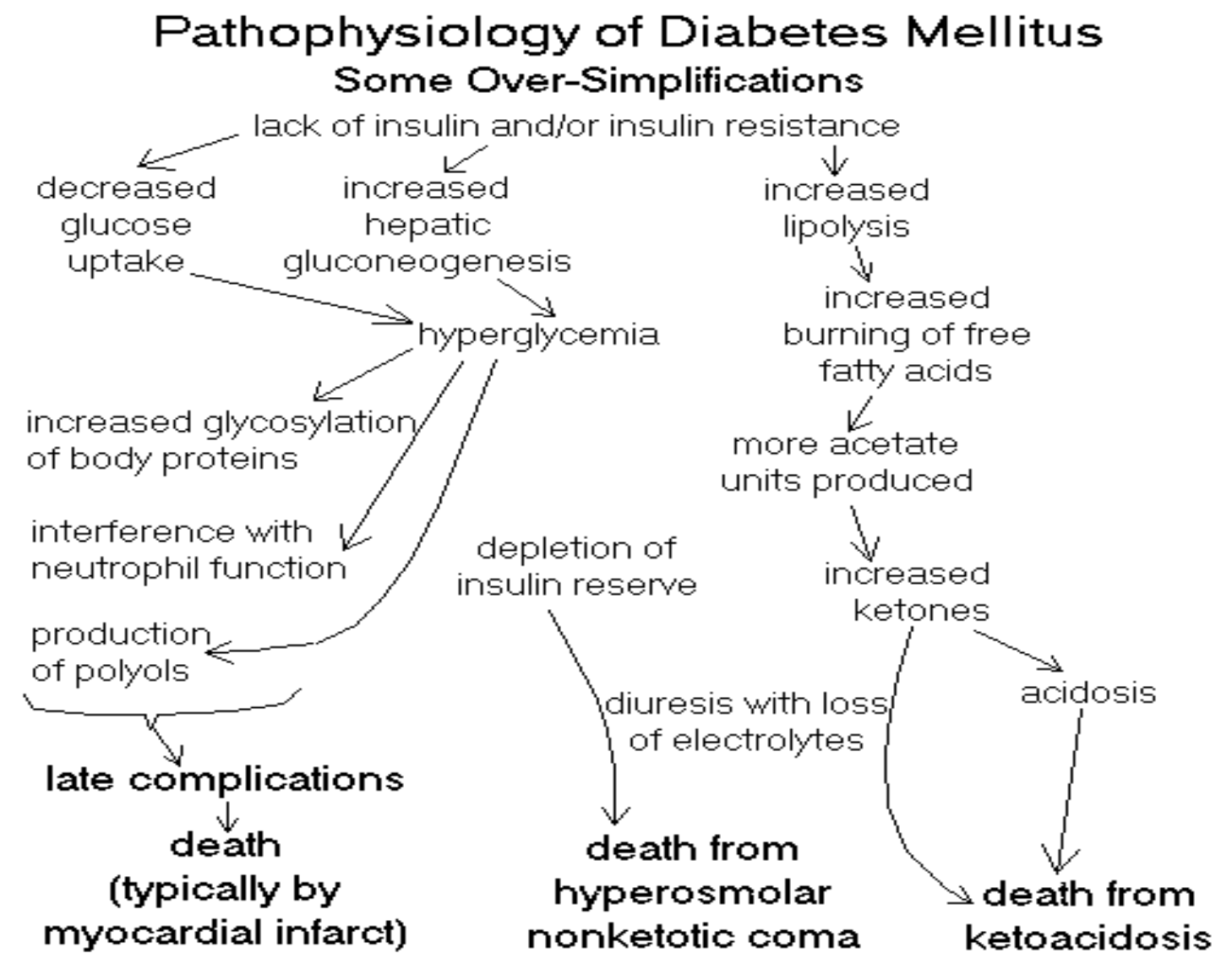

Figure 2: Pathophysiology of Diabetes Mellitus

Source: KrishnaDas, 2008

\subsection{Symptoms of Diabetes Mellitus}

Diabetes symptoms vary depending on blood sugar level of individual with diabetes. Type 2 diabetes, in particular, develops slowly. Many people have type 2 diabetes for as long as eight years before it is diagnosed. When symptoms do develop, they often vary. But two symptoms that occur in many people with the disease are increased thirst (polydipsia) and frequent urination (polyuria) due to excess glucose circulating in the body draws water from the tissues, making diabetics feel dehydrated. To quench the thirst, they drink a lot of water and other beverages, and that leads to more frequent urination (Davidson et al., 2003). Other warning symptoms of diabetes mellitus are fatigue, irritability, blurred vision, slow-healing sores, frequent infections (such as gums or skin infections and vaginal infections), presence of ketones in the urine (ketones are byproduct lipid catabolism), nerve damage, etc. (Taiwo, 2010).

\subsection{Causes of Diabetes Mellitus}

Diabetes mellitus is caused by a complicated interplay of genes, environment, insulin abnormality, increased glucose production in the liver, increased fat breakdown and possible defective hormonal secretion in the intestine. The recent dramatic increase indicates that factors such as obesity and sedentary lifestyle may be particularly important in triggering genetic elements that cause diabetes mellitus (Davidson et al., 2003).

\subsection{Classifications of Diabetes Mellitus}

Assigning a type of diabetes to an individual often depends on the circumstances present at the time of diagnosis, and many diabetic individuals do not easily fit into a single class. 
For example, a person with gestational diabetes mellitus may continue to be hyperglycaemic after delivery and may be determined to have, in fact, type 2 diabetes. Alternatively, a person who acquires diabetes because of large doses of exogenous steroids may become normoglycaemic once the glucocorticoids are discontinued, but then may develop diabetes many years later after recurrent episodes of pancreatitis (Baynes, 2015). However, there are two major types of diabetes. These are type 1 and type 2 diabetes. The other types are less common and they include gestational diabetes or pregnancy-induced diabetes and other specific type (Sicree et al., 2006)

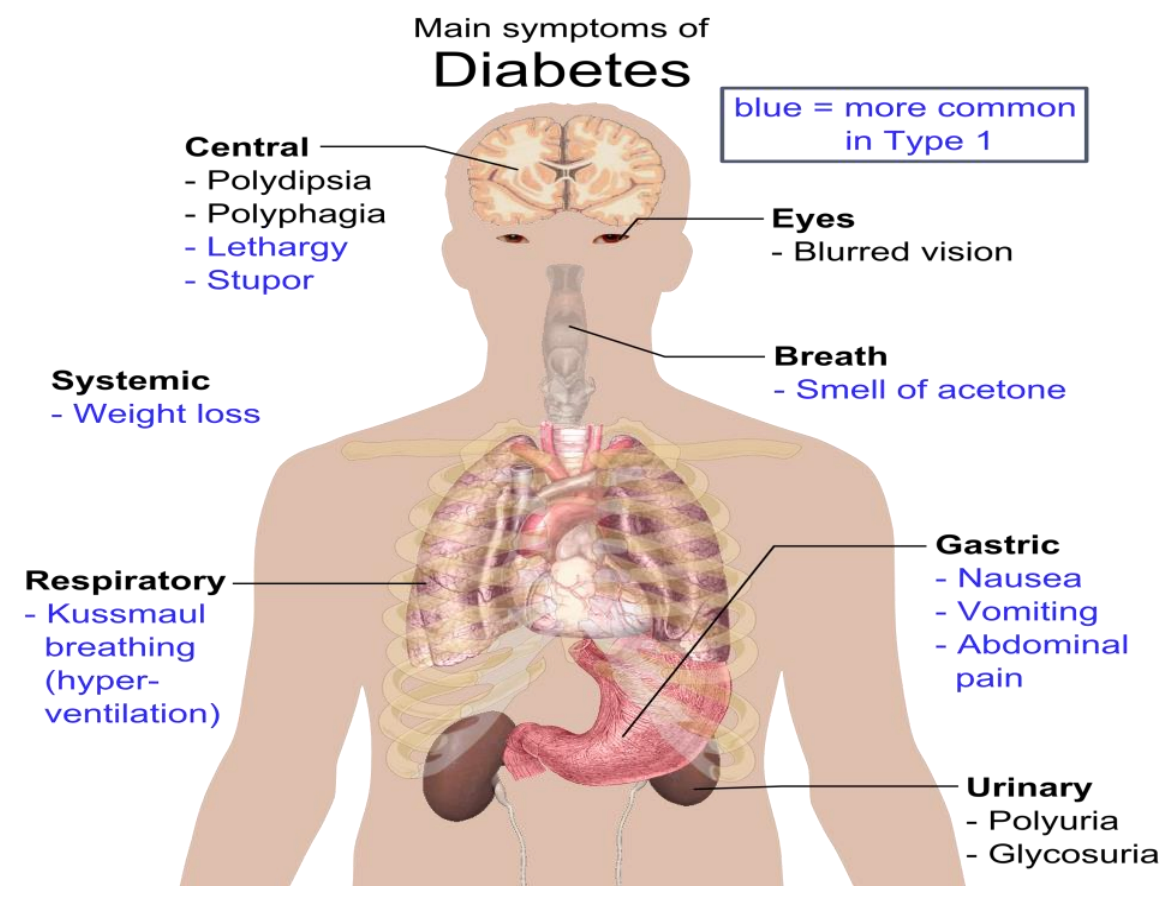

Figure 3: Overview of the most significant symptoms of diabetes

Sources: Davidson et al., 2003

\subsubsection{Type 1 Diabetes Mellitus}

Type 1 diabetes is often known as insulin-dependent diabetes. Since it starts in children and in the young, it is also termed juvenile diabetes or early-onset diabetes. Type 1 diabetes mellitus is characterized by beta cell destruction caused by an autoimmune process, usually leading to absolute insulin deficiency (Kumar and Clark, 2002). Type 1 is usually characterized by the presence of anti-glutamic acid decarboxylase (anti-GAD) antibodies, islet cell or insulin antibodies that target an enzyme called glutamic acid carboxylase. This enzyme converts glutamic acid to gamma amino butyric acid (GABA), a neurotransmitter found in high concentration in the cerebellum. Eventually, all type1 diabetic patients will require insulin therapy to maintain normoglycaemia (Baynes, 2015).

\subsubsection{Type 2 Diabetes Mellitus}

Type 2 diabetes is otherwise called non-insulin dependent diabetes mellitus (NIDDM). Type 2 diabetes is a heterogenous disorder caused by a combination of genetic factors related to impaired insulin secretion, insulin esistance and environmental factors such as obesity, over eating, lack of exercise, and stress as well as aging (Kaku, 2010). It is typically a multifactorial disease involving multiple genes and environmental factors to varying extents (Holt, 2004). Type 2 diabetes is the predominant form of diabetes and accounts for at least $90 \%$ of all cases of diabetes mellitus (Gonzalez et al., 2009). The rise in prevalence is predicted to be much greater in developing than in developed countries (69\% versus 20\%) (Shaw et al., 2010). This increase in type 2 diabetes is inextricably linked 
to changes towards a western lifestyle (high diet with reduced physical activity) in developing countries and the rise in prevalence of overweight and obesity (Chan et al., 2009). The American Diabetes Association (ADA) recommends that testing to detect prediabetic should be considered in adults who are overweight or obese and have one or more risk factors for diabetes (Diabetes Prevention Program Research Group, 2009).

\subsubsection{Gestational Diabetes Mellitus or Pregnancy- Induced Diabetes Mellitus}

Gestational diabetes mellitus (GDM) is associated with women who develop Type 1 diabetes mellitus during pregnancy and women with undiagnosed asymptomatic Type 2 diabetes mellitus that is discovered during pregnancy. In most women who develop GDM; the disorder has its onset in the third trimester of pregnancy (Baynes, 2015).

\subsubsection{Other specific type (Monogenic diabetes)}

Types of diabetes mellitus of various known etiologies are grouped together to form the classification called "Other Specific Types". This group includes people with genetic defects of beta-cell function (this type of diabetes was formerly called MODY or maturity-onset diabetes in youth) or with defects of insulin action; people with diseases of the exocrine pancreas, such as pancreatitis or cystic fibrosis; people with dysfunction associated with other endocrinopathies (e.g. acromegaly); and people with pancreatic dysfunction caused by drugs, chemicals or infections and they comprise less than $10 \%$ of DM cases ( Baynes, 2015).

\subsection{Diagnoses of Diabetes Mellitus}

The starting point for living well with diabetes is an early diagnosis - the longer a person lives with undiagnosed and untreated diabetes, the worse the health outcomes are likely to be. Easy access to basic diagnostics for diabetes is therefore essential and diagnosis should be available in primary health-care settings (American Diabetes Association, 2000).

Type 1 diabetes often presents with symptoms that prompt the patient to contact health services -thirst, weight loss and copious urination. Type 2 diabetes often shows no symptoms, and some patients contact health services because of a complication such as vision loss, heart attack or limb gangrene. Type 2 diabetes develops slowly and there is often a very long period of time in which the disease is present but undetected (American Diabetes Association, 2011).

The identification of patients with diabetes or pre-diabetes by screening allows for earlier intervention, with potential reductions in future complication rates (Baynes, 2015). The 1997 American Diabetes Association (ADA) recommendations for diagnosis of diabetes mellitus focus on Fasting Plasma Glucose (FPG), while WHO focuses on the Oral Glucose Tolerance Test (OGTT) (Gillett, 2009). A clinician draws blood after a night of fasting and measures an indicator of blood glucose to determine whether it falls within normal range. Diabetes mellitus can be screened for diagnosis by one of the 3 methods;

Random Blood Glucose Test: Diabetes is diagnosed on the basis of a single abnormal plasma glucose reading. When taken randomly at any time of the day, the levels are considered high if they are $11.1 \mathrm{mmol} / \mathrm{L}$ or higher (Gillett, 2009).

Fasting Blood Glucose (FBG): This is usually taken after an overnight fast. Blood glucose level of $7 \mathrm{mmol} / \mathrm{L}(126 \mathrm{mg} / \mathrm{dL})$ or higher is considered positive for diabetes when other diabetic symptoms such as thirst, increased urination, recurrent infections, weight loss or drowsiness are present (Gillett, 2009).

Oral Glucose Tolerance Test (OGTT): This blood tes evaluates body's response to glucose and require the patient to fast for at least eight hours but not more than sixteen hours (overnight fast). A fasting blood sugar level is measured, then 75 gm glucose or any sugary drink is given to the patient and the blood sugar levels are tested periodically (every 30 minutes to 1 hour) for 2 hours. A blood sugar level less than $140 \mathrm{mg} / \mathrm{dL}(7.8 \mathrm{mmol} / \mathrm{L})$ is normal, $140 \mathrm{gm} / \mathrm{dL}-199 \mathrm{mg} / \mathrm{dL}(7.8 \mathrm{mmol} / \mathrm{L}-11.0$ $\mathrm{mmol} / \mathrm{L}$ ) indicates prediabetes, and a reading of $200 \mathrm{mg} / \mathrm{dL}$ (11.1 $\mathrm{mmol} / \mathrm{L})$ or higher after 2 hours indicates diabetes (Mayo Foundation for Medical Education and Research, 2016). An abnormal screening test result should prompt clinician to repeat the same test or perform another test to confirm the diagnosis. 


\subsection{Management of Diabetes Melliitus}

Currently, the goal of diabetes management is to avoid or minimize chronic diabetic complications, as well as to avoid acute problems of hyperglycaemia or hypoglycaemia. Adequate control of diabetes leads to lower risk of complications associated with unmonitored diabetes including kidney failure (requiring dialysis or transplant), blindness, heart disease and limb amputation. The most prevalent form of medication is hypoglycaemic treatment through either oral hypoglycaemics and/or insulin therapy (Tuomilehto., et al., 2001).

The management of diabetes mellitus includes; diet, physical exercise, insulin therapy and oral hypoglycaemic agents such as sulphonylureas, Biguanides, thiazolidinediones, alpha glucosidase inhibitors and Metformin. These drugs work in either two ways: They improve sensitivity of body cells to insulin or Reduce synthesis of glucose in the liver. If a person with Diabetes mellitus cannot secrete enough insulin, the patient must take daily injections of insulin (American Diabetes Association, 2000).

Patients with type 1 diabetes mellitus require direct injection of insulin as their bodies cannot produce enough (or even any) insulin. As of 2010, there is no other clinically available form of insulin other than injection for patients with type 1: injection can be done by insulin pump, by jet injector, or any of several forms of hypodermic needle. Noninjective methods of insulin have been unattainable as the insulin protein breaks down in the digestive tract (Mealey, 2006). For type 2 diabetics, diabetic management consists of a combination of diet, exercise, and weight loss, in any achievable combination depending on the patient. Obesity is very common in type 2 diabetes and contributes greatly to insulin resistance. Weight reduction and exercise improve tissue sensitivity to insulin and allow its proper use by target tissues (Mealey, 2006).

Diet is an important component of diabetes treatment. To maintain near-normal blood glucose levels, diet is designed to deliver the same amount of carbohydrate each day, spaced evenly throughout the day. People with diabetes should follow most of the same dietary guideline recommended for those without diabetes. The difference is that people with diabetes mellitus may need to eat less carbohydrate, slightly more fat or protein to help regulate blood glucose level (American Diabetes Association, 2000).

\subsection{The Concept of Nutrition}

Nutrition is the science that interprets the interaction of nutrients and other substances in food in relation to maintenance, growth, reproduction, health and disease of an organism. It includes food intake, absorption, assimilation, biosynthesis, catabolism and excretion. The diet of an organism is what it eats, which is largely determined by the availability, the processing and palatability of foods. A healthy diet includes preparation of food and storage methods that preserve nutrients from oxidation, heat or leaching, and that reduce risk of foodborne illness. A poor diet may cause health problems, causing deficiency diseases such as blindness, anemia, scurvy, preterm birth, stillbirth and cretinism; healththreatening conditions like obesity and metabolic syndrome; and such common chronic systemic diseases as cardiovascular disease, diabetes, and osteoporosis. A poor diet can cause the wasting of kwashiorkor in acute cases, and the stunting of marasmus in chronic cases of malnutrition (Whitney and Sharon, 2013).

A nutrient is a component in foods that an organism uses to survive and grow. Macronutrients provide the bulk energy an organism's metabolic system needs to function while micronutrients provide the necessary cofactors for metabolism to be carried out. Both types of nutrients can be acquired from the environment. Micronutrients are used to build and repair tissues and to regulate body processes while macronutrients are converted to, and used for, energy. Methods of nutrient intake are different for plants and animals. Plants take in nutrients directly from the soil through their roots and from the atmosphere through their leaves. Animals and protists have specialised digestive systems that work to break down macronutrients for energy and utilize micronutrients for both metabolism and anabolism (constructive synthesis) in the body (Whitney and Sharon, 2005).

A healthy and balanced diet should provide enough calories for the daily energy requirement to maintain or achieved reasonable body weight, to provide for the needs of pregnant and lactating women, to allow for normal growth in children and adolescents and to satisfy the needs of aged people.

Citations: Muhammed D, Adebiyi YH, Odey BO, Ibrahim J, Hassan ON, Ugwunnaji PI, and Berinyuy E.B. (2021). Nutritional Management of Diabetes Mellitus: An appraisal of the role of Medicinal plants. AROC in Natural Product Research. 01(01), 001-027 


\subsection{Types of Nutrients}

Nutrients can be classified in two ways;

Classification based on their synthesis: based on this classification, nutrients can be classified into essential and non- essential nutrients. The e are those that cannot be synthesised in the body (either at all, or in sufficient quantities), and so must be consumed by an organism from its environment. For humans, these include essential fatty acids, essential amino acids, vitamins, and certain dietary minerals. Oxygen and water are also essential for human survival, but are generally not considered "food" when consumed in isolation. There are no "essential carbohydrates", animals can synthesise all the types of carbohydrates needed for growth. Humans can derive energy from a wide variety of fats, carbohydrates, proteins, and simple chemicals such as ethanol and acetic acid (John et al., 2009). The nonessential nutrients are those nutrients that can be synthesized in the body; they may often also be absorbed from consumed food. The majority of animals ultimately derive their essential nutrients from plants. Interest has recently increased in phytochemicals, which include many non-essential substances which may or may not have health benefits (John et al., 2009).

2. Classification based on the quantity required: nutrients are classified into macronutrients and micronutrients.

\subsubsection{Macronutrients}

Macronutrients are defined as a class of chemical compounds which humans consume in the largest quantities (must be above a threshold amount) and which provide humans with the bulk of energy. The macronutrients are carbohydrates, fiber, fats, protein, and water (Fuhrman, 2014). The macronutrients (excluding fiber and water) provide structural material (amino acids from which proteins are built, and lipids from which cell membranes and some signaling molecules are built) and energy. Carbohydrates and proteins provide $17 \mathrm{~kJ}$ approximately ( $4 \mathrm{kcal}$ ) of energy per gram, while fats provide $37 \mathrm{~kJ}$ ( $9 \mathrm{kcal})$ per gram (Jeffrey, 2006), though the net energy from either depends on such factors as absorption and digestive effort, which vary substantially from instance to instance. Vitamins, minerals, fiber, and water do not provide energy, but are required for other reasons (Berg et al., 2002).

\subsubsection{Carbohydrate}

Glucose is an essential metabolic substrate of all mammalian cells. D-glucose is the major carbohydrate presented to the cell for energy production and many other anabolic requirements. Glucose and other monosaccharides are transported across the intestinal wall to the hepatic portal vein and then to liver cells and other tissues. There they are converted to fatty acids, amino acids, and glycogen, or are oxidized by the various catabolic pathways of cells (Bjornholm and Zierath, 2005). Most tissues and organs, such as the brain, need glucose constantly, as an important source of energy. The low blood concentrations of glucose can cause seizures, loss of consciousness, and death. On the other hand, long lasting elevation of blood glucose concentrations, can result in blindness, renal failure, vascular disease, and neuropathy. Therefore, blood glucose concentrations need to be maintained within narrow limits. The process of maintaining blood glucose at a steady-state level is called glucose homeostasis (Guettier and Gorden, 2006)

This is accomplished by the hormonal regulation of glucose uptake and hepatic glucose production. This maintenance is achieved through a balance of several factors, including the rate of consumption and intestinal absorption of dietary carbohydrate, the rate of utilization of glucose by peripheral tissues and the loss of glucose through the kidney tubule and the rate of removal or release of glucose by the liver and kidney. To avoid postprandial hyperglycaemia (uncontrolled increases in blood glucose levels following meals) and fasting hypoglycaemia (decreased in blood glucose levels during periods of fasting), the body can adjust blood sugar levels by a variety of cellular mechanisms. Important mechanisms are conveyed by hormones, cytokines, and fuel substrates and are sensed through of cellular mechanisms (Bjornholm and Zierath, 2005).

\subsubsection{Protein}

Proteins consist of long chains of subunits called amino acids. As the name implies, each amino acid contains an amino group $\left(\mathrm{NH}_{2}\right)$ on one end of the molecule and a carboxylic acid group $(\mathrm{COOH})$ on another end. There are approximately twenty different amino acids, each with a distinct structure and chemical properties that are used to build proteins (Mathews et al. 2000). When amino acids are joined, the hydrogen from the amino end of one amino acid

Citations: Muhammed D, Adebiyi YH, Odey BO, Ibrahim J, Hassan ON, Ugwunnaji PI, and Berinyuy E.B. (2021). Nutritional Management of Diabetes Mellitus: An appraisal of the role of Medicinal plants. AROC in Natural Product Research. 01(01), 001-027 
combines with the hydroxyl group of carboxylic end of another amino acid. The bond between adjacent amino acids is called a peptide bond, and the compound formed is called a peptide Two amino acids bound together is called a dipeptide; three, a tripeptide (Manninen, 2002).

The most critical aspects of protein metabolism that occur in the liver are: Deamination and transamination of amino acids, followed by conversion of the non-nitrogenous part of those molecules to glucose or lipids. Several of the enzymes used in these pathways (for example, alanine and aspartate aminotransferases) are commonly assayed in serum to assess liver damage (Felig 2005).

\subsubsection{Lipids}

Fatty acid (FA) is the major component of almost all lipid classes (except sterols) and also serves as carbon sources for energy production through $\beta$-oxidation and oxidative phosphorylation on shortage of glucose. Triacylglyceride (TAG), one of the major neutral lipids, is composed of three fatty acids (FAs) esterified to a glycerol backbone. The three FAs influence the chemical and physical characteristics of TAG by the length of carbon chains and degree of desaturation. The esterification happens between three hydroxyl groups $(-\mathrm{OH})$ on the glycerol molecule and carboxyl groups $(-\mathrm{COOH})$ on each of the three FA molecules. The most important function of TAGs is to efficiently store energy in the form of FAs, thereby preventing the potential toxicity of excessive free fatty acids (FFAs). Assembled and secreted in mammal intestines and livers, TAGs are also important for transporting FAs to different tissues throughout the body (Mathews et al. 2000).

\section{Metabolic Pathways of Macronutrients}

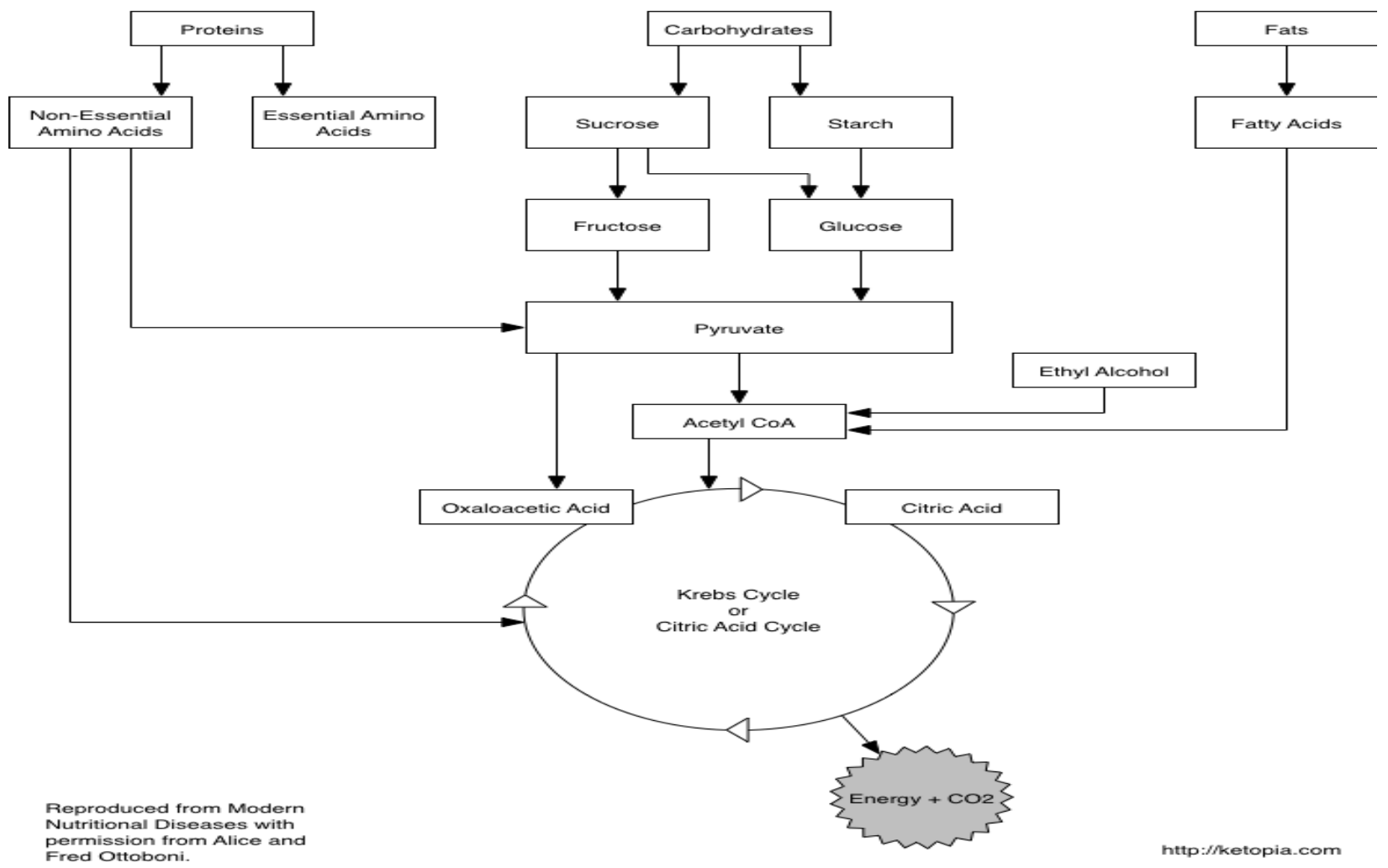

Figure 4: metabolic pathways of macronutrients

Source: Alice and Fred, 2013 


\subsubsection{Micronutrients}

Micronutrients are essential dietary components and play fundamental role in the prevention of disease. Micronutrients are vitamins and minerals that our bodies require in small quantities for specific functions. They most commonly function as essential coenzymes and cofactors for metabolic reactions and thus help support basic cellular reactions (i.e., glycolysis, the citric acid cycle, lipid and amino acid metabolism) required to maintain energy production and life (Belinda, 2001). Micronutrients have an array of biochemical functions which are fundamental in the homoeostatic regulation of body function. Micronutrients can be obtained from different sources such as those that are intrinsic within the tissue matrix and fluid of edible plant and animals. Those that are from extrinsic sources will include nutrients that are added to foods such as with fortification of specific nutrients (thiamine to white flour, iodine added to salt) (Belinda, 2001).

\subsubsection{Minerals}

They are essential micronutrients that are required in diet in relatively small quantities from few micrograms to few milligrams (mg) per day by the body. Minerals that are considered essential are calcium, phosphorus, magnesium, sodium, potassium, iron, zinc, and fluoride (semi-essential). Trace elements considered essential are copper, chromium, manganese, molybdenum, selenium, and iodine (Rita, 2015)

\subsubsection{Vitamins}

They were first identified from the overt deficiency states that resulted from inadequate intakes causing conditions such as scurvy, beriberi and pellagra. Suboptimal intakes can be seen in sub-groups of populations and can cause adverse effects on health, particularly long term. Vitamins are subdivided into two groups: the fat soluble vitamins which include vitamins A, D, E and $\mathrm{K}$ and the water soluble vitamins which include B vitamins and vitamin C (Rita, 2015)

\subsection{Nutritional Management of Diabetes}

Nutrition is often said to be the cornerstone of diabetes care. The nutritional management of diabetes can affect long term health and quality of life. The goal for nutritional management is optimal metabolic control through a balance between food intake, physical activity, and if necessary, medication to avoid complications (American Diabetes Association, 2008).

The major goal for diabetes care is to improve glycaemic control by balancing food intake with endogenous and/or exogenous insulin levels. For people with type 1 diabetes, insulin doses need to be adjusted to balance with nutritionally adequate food intake and physical activity. For individuals with type 2 diabetes, impaired glucose tolerance or impaired fasting glucose, attention to food portions and weight management combined with physical activity may help improve glycaemic control. Nutrition and all forms of diabetes management should be individualised (Smart et al., 2009).

Evidence available from America from the Diabetes Control and Complications Trial in Type 1 diabetes (The Diabetes Control and Complications Trial Research Group, 1993) and also from the United Kingdom Prospective Diabetes Study in Type 2 diabetes (UK Prospective Diabetes Study (UKPDS) Group, 1998) suggests that normalisation of metabolic markers like blood glucose levels and management of blood pressure constitute key aims of the nutritional management of diabetes. Other aims of nutritional management of diabetes are:

1. Encourage appropriate eating behavior and healthy lifelong eating habits whilst preserving social, cultural and psychological well-being;

2. Three balanced meals a day, with appropriate healthy snacks (if necessary), will supply all essential nutrients, maintain a healthy weight, prevent bingeing and provides a framework for regular monitoring of blood glucose levels;

3. Provide sufficient and appropriate energy intake and nutrients for optimal growth, development and good health;

4. Achieve a balance between food intake, metabolic requirements, energy expenditure and insulin action profiles to attain optimum glycaemic control;

5. Prevent and treat acute complications of diabetes such as hypoglycaemia, hyperglycaemic crises, illness and exerciserelated problems;

Citations: Muhammed D, Adebiyi YH, Odey BO, Ibrahim J, Hassan ON, Ugwunnaji PI, and Berinyuy E.B. (2021). Nutritional Management of Diabetes Mellitus: An appraisal of the role of Medicinal plants. AROC in Natural Product Research. 01(01), 001-027 


\subsection{Dietary Recommendation for Diabetics}

\subsubsection{Macronutrient Requirements}

The macronutrient requirements for diabetic patients are carbohydrate, protein and lipid.

\subsubsection{Carbohydrates}

Carbohydrates are the body's main energy source; $50 \%$ $55 \%$ of the daily caloric intake should be provided by them (American Diabetes Association, 2002). Based on the individual's glucose needs, weight status, lipid profile, and eating habits, carbohydrate intake should be individualised. It is important that people with either type 1 or type 2 diabetes consume the right amount of carbohydrates, as they are the primary energy source for the central nervous system which depends on blood glucose. Carbohydrates also have the role of 'protein sparer', preventing the use of proteins for energy purposes, allowing them to perform their real role in tissue building and as metabolic primers for fat metabolism. The amount of carbohydrates in the diet regulates the levels of the intermediate products of fat metabolism, ketones. If the amount of carbohydrates is too low or unavailable, fat is oxidized for energy purposes with an increase of ketones resulting in keto-acidosis, which is a common problem in patients with type 1 diabetes (Arnoldi, 2004).

Simple sugars are thought to be absorbed quickly, thus rapidly increasing the level of blood sugars and so were forbidden. However, the ADA Position Statement 2002 has concluded that for people with diabetes it is the total amount of carbohydrates in meals and snacks, rather than the type, that determines the glycaemic response. Sugars, however, should be restricted in the diet, as a high intake usually increases triglyceride levels in the blood and may also contribute to the development of dental caries (American Diabetes Association, 2002). Moreover, sugars are usually associated with high-calorie foods, which should be limited in order to maintain a healthy body weight. Their amount should not be more than 10 per cent of the daily total energy intake. Polysaccharides are preferred, especially those containing fibre, since the more fibre food contains, the more slowly it is digested, raising blood sugar levels at a slower rate (European Diabetes Policy Group, 1999).
A system for classifying carbohydrates, known as the glycaemic index (GI), measures the effect that a food has on blood sugar levels. Foods that have a high glycaemic index cause a rapid and strong rise in blood sugar levels; diets filled with these foods have been linked to an increased risk for both diabetes and heart disease. Various factors, including the degree of processing, physical form and fibre content, determine a food's glycaemic index. Therefore, the glycaemic index relates to the quality and not the quantity of carbohydrates consumed (Arnoldi, 2004).

Foods that contain complex carbohydrates, such as potatoes, quickly raise blood sugar levels, whereas foods that contain simple carbohydrates, such as whole fruit, raise blood sugar levels more slowly. Fruits and milk have been shown to have lower glycaemic responses than most starches (Leonid, 2009). Sucrose produces a response similar to common starches like rice, potato, and bread. Although various starches per gram of carbohydrate do have different effects on blood sugar, for purposes of dietary planning it is the total amount of carbohydrate consumed rather than the source that merits primary consideration (Leonid, 2009).

Another dietary sugar, fructose, produces smaller blood glucose increase than sucrose and has been proposed as a "natural" sweetener. The moderate consumption of fructose-containing foods has presented no problem, but when fructose is consumed in large amounts, up to $20 \%$ of the calories, it is known to adversely affect blood lipids (Leonid, 2009). The sweeteners that have calories from carbohydrate like fruit juice concentrates, molasses, honey, and corn syrup have direct effects on blood sugar similar to sucrose and offer no advantage to persons with diabetes. Nonnutritive sweeteners are encouraged for people with diabetes to add increased variety to their food choices (American Diabetes Association, 2008).

The daily intake of carbohydrates will depend upon the type of exercise programme, the amount and timing of daily insulin requirement, the use of an insulin pump, the need to lose weight or for a special diet to reduce cholesterol or blood pressure levels. Food such as honey, syrup, jam, jelly, candy, sweet rolls, regular gelatin, cake with icing, and pie should be avoided, as should soft drinks. The consumption of the so-called products for diabetics, such as chocolate, should also be restricted as they contain excess calories in fat.

Citations: Muhammed D, Adebiyi YH, Odey BO, Ibrahim J, Hassan ON, Ugwunnaji PI, and Berinyuy E.B. (2021). Nutritional Management of Diabetes Mellitus: An appraisal of the role of Medicinal plants. AROC in Natural Product Research. 01(01), 001-027 


\subsubsection{Fibre}

For years fiber has received much attention for its disease prevention effects in the general population. Fibre is the indigestible part of plant foods (Nuttall, 1993). There are two types of fibre: soluble and insoluble. Recently the literature is replete with articles demonstrating improved blood glucose management in both type 1 and type 2 diabetes with high-fiber diets (Wylie-Rosett et al., 2004).

Fiber-rich foods such as beans or cereals with 5 or more grams of fiber per serving and fruits and vegetables are emphasised due to their nutrient content (Liese et al., 2005). Both soluble and insoluble fibers are encouraged in amounts similar to the recommendations for the general population (20-35 g or $14 \mathrm{~g} / 1000 \mathrm{cal}$ ) (Liese et al., 2005). Soluble fibres, such as gums and mucilages, form gels with pectin or gums in the intestine and thus slow the rate of nutrient absorption, helping to reduce postprandial glucose levels. Insoluble fibres, such as lignins, celluloses and hemicelluloses, increase bulk and decrease transit time. Both types are useful as they prolong gastric emptying, shorten intestinal transit time, prevent constipation and bind cholesterol, thus limiting its absorption. Food rich in fibre include vegetables, fruits, whole wheat, bran, cereals and legumes. An adequate diet should provide 30 grams of fibre a day (Arnoldi, 2004).

\subsubsection{Proteins}

At the current time no data are available to indicate that the protein needs of persons with diabetes are different from the dietary reference intake (DRI) for the general population, $15-20 \%$ of total caloric intake, $0.8-1 \mathrm{~g} / \mathrm{kg}$ body weight (Franz, 2002 b). This amount should increase during pregnancy, breast feeding, infancy and childhood, illness and diseases.

Proteins, unlike fats and carbohydrates, contain nitrogen. Proteins are normally not energy suppliers, but in cases of stress, diseases or fasting, when there is either an increased need of energy or the caloric intake is not sufficient to cover the body needs, they are used to provide energy. Thus, a diet with the right amount of carbohydrate has a proteinsparing effect. However, dietary protein intake must be balanced, as large amounts can cause gout or kidney stones in some individuals, as purine breaks down to uric acid, and high concentrations can crystallise in the kidneys and joints.
Moreover, excess nitrogen is a burden for the kidneys and animal food proteins are also rich in fat, especially saturated types, which cause cardiovascular disease and obesity. According to the ADA dietary guidelines, the intake of protein in the usual range does not appear to be associated with the development of diabetic nephropathy, although it is advisable to avoid intakes superior to 20 per cent of the total daily energy (American Diabetes Association, 2011).

\subsubsection{Lipids}

As people with diabetes have an increased risk of heart and blood vessel diseases, a normal to low-fat diet is advisable in order to reach and maintain good weight and health. As part of a healthy diet, $30 \%$ of daily calories should come from fats and of these less than $10 \%$ should be saturated fat, less than $10 \%$ polyunsaturated fat and $10-15 \%$ monounsaturated fat (American Diabetes Association, 2008). However, a diet with a low intake of fat can be dangerous since not only is fat a major source of energy for the body as it supplies $9 \mathrm{kcal} / \mathrm{g}$, it is also the source of essential fatty acids (EFA), such as linoleic, linolenic and arachidonic acids. These are called 'essential' as the body cannot synthesize them and they are needed for a number of key functions such as transport and metabolism of cholesterol, precursors of prostaglandins and others. Among the EFA, omega-3 fatty acids found in fish, especially salmon, mackerel and herring, have been shown to lower plasma triglyceride levels in patients with type 2 diabetes (American Diabetes Association, 2008).

Monounsaturated fat is a type of unsaturated fat that lowers blood low density lipoprotein (LDL) cholesterol levels (Berry et al., 1991). It is also resistant to oxidation. This is important since oxidation enables cells in arteries to absorb fats and cholesterol and helps accelerate the formation of plaques. This type of fat is found in olive oil, avocados, canola oil, etc. In people with diabetes a diet higher in monounsaturated fats and lower in carbohydrates has been shown to reduce postprandial glycaemia and triglyceridaemia, but it is not recommended for someone with type 2 diabetes as it may cause weight gain (Lichtenstein and Deckelbaum, 2001). Monounsaturated fats and carbohydrate intake should be based on dietary goals and metabolic profile of each individual.

The effects of polyunsaturated fat on subjects with diabetes have not been well studied. Compared with 
monounsaturated fat, this vegetable fat lowers total blood cholesterol but is susceptible to oxidation, which as previously described may ultimately lead to coronary artery disease. Polyunsaturated fats are found in cottonseed, soybean, sunflower and safflower oils. Saturated fat is an animal fat that raises total blood cholesterol and increases the risk for coronary artery disease (National Cholesterol Education Program, 2001). It is found in hydrogenated vegetable fats, coconut and palm oils, cocoa butter, meat fat, whole milk, butter cream and fatty cheeses. Cholesterol blood levels should be kept to $<200 \mathrm{mg} / \mathrm{dL}$ and the daily intake should be limited to 300 $\mathrm{mg} /$ day. According to the ADA recommendations, diabetics with dyslipidaemia, such as those with high LDL cholesterol, should lower saturated fats to less than 7 per cent and dietary cholesterol to $200 \mathrm{mg} /$ day and increase soluble fibre to $10-25 \mathrm{~g} /$ day, together with physical activity (American diabetes association, 2011). Also plant sterol and stanol esters have been shown to have a good effect on blocking the absorption of total and LDL cholesterol (Lichtenstein and Deckelbaum, 2001).

A healthy diet should be rich in fish, poultry (without skin), lean cuts of beef, lamb, veal, pork, skimmed or low-fat milk, low-fat cheeses, low-fat yogurt, olive oil, rice, pasta, bread, whole-grain cereals, legumes, vegetables and fruits, while intake of foods such as animal fats, bacon, sausages, commercially baked goods, cream, cheeses, butter, salad dressings made with cream and eggs and junk food such as potato chips, cookies should be cut down. Particular attention must be made to margarine or shortening, which contain hydrogenated vegetable oils, which consequently form trans-fatty acids. These are highly related with artery disease, raising blood cholesterol and lowering HDL levels (Arnoldi, 2004).

\subsubsection{Micronutrient requirements}

As the general population, people with diabetes have no need for vitamin and mineral supplementation when the dietary intake is adequate. Only in certain cases such as illness, stress or pregnancy is a higher intake required.

\subsubsection{Vitamins}

Many physicians prescribe a pill containing the reference dietary intake (RDI) of the established vitamins as an "insurance policy." For the elderly with reduced energy intake, a multivitamin supplement is commonly given. With the increased risk for heart disease and its adverse outcome in persons with diabetes, antioxidants may be prescribed, but there is little evidence that this practice is beneficial (Yusuf et al., 2000).

High doses of dietary antioxidants such as vitamins $\mathrm{C}$ and $\mathrm{E}$, beta-carotene and other carotenoids have been prescribed to people with diabetes (Ylonen et al., 2003). Antioxidants are substances that neutralize the action of free radicals, which are molecules that damage cells, and increase the risk of cancer and heart diseases. In this case, they are thought to protect LDL and PUFA from oxidation. Supplementary intakes of vitamin D seem to lead to an improvement in lipid metabolism in type 2 diabetes sufferers, especially in combination with physical exercise. Experimental research produced evidence that vitamin D can help prevent the destruction of insulin-producing pancreatic beta cells and thus combat the onset of type 1 diabetes. It is assumed that this is due primarily to the immunomodulatory action of the vitamin via T-helper cells and to the reduction of proinflammatory cytokines (Zipitis and Akobeng, 2008).

The antioxidant status of a diabetic can be significantly improved by administration of vitamin $\mathrm{C}$, which reduces protein glycosylation by competitively displacing glucose from the amino groups of proteins. In this way the vitamin prevents endothelial damage induced by glycosylated reaction products and improves endothelium function (Meredith et al., 2014). Vitamin C also reduces aldose reductase (figure 5) and hence slows the intracellular accumulation of the sugar alcohol sorbitol, which can cause

damage to nerves, eyes and kidneys (Cunningham et al., 1994). In a randomized controlled study with type 2 diabetics, adjunctive administration of 2 x $500 \mathrm{mg}$ vitamin $\mathrm{C}$ per day for a period of four months led to a significant decrease in insulin resistance, $\mathrm{HbA} 1 \mathrm{C}$ values and plasma levels of total cholesterol, LDL cholesterol and triglyceride, compared with placebo (Paolisso et al., 1995). Further, supplementary administration of vitamin $\mathrm{C}$ appears to enhance the metabolic regulatory activity of the antidiabetic medication metformin (Dakhale et al., 2011) and to have a positive effect on complications like depression (Mazloom et al., 2013) and periodontitis (Gokhale et al., 2013) in diabetics. 
As a highly effective antioxidant, vitamin E protects enzymes and hormones, as well as the polyunsaturated fatty acids of biological membranes and LDL, against oxidation by oxygen radicals. During this process vitamin E is oxidized and must be regenerated by vitamin $\mathrm{C}$ or flavonoids. In this way the vitamin combats the oxidative degradation of fatty acids (lipid peroxidation) and in particular the oxidative modifications of LDL that contribute to the incidence of atherosclerosis. Moreover, vitamin E lowers thrombocyte aggregation and hence the risk for thrombosis. In addition, by inhibiting enzymes, vitamin E slows inflammatory processes and the proliferation of connective tissue in the blood vessels and therefore reduces the threat or advance of diabetic complications (Montero et al., 2014). However, according to the ADA dietary guidelines (2002), routine supplementation of the diet with antioxidants is not advised because of uncertainties related to long- term efficacy and safety.

As coenzymes the $\mathrm{B}$ vitamins play a central role in carbohydrate, protein and lipid metabolism. A diabetic metabolic status is characterized by both higher requirements and increased renal elimination of $B$ vitamins, especially when the diabetes is not well managed. Studies indicate that the majority of type 1 and type 2 diabetics have inadequate supplies of vitamin B1 and impaired thiamine metabolism (Thornalley et al 2007). A tissue-specific vitamin B1 deficiency (e.g., in the kidneys) can increase the risk of vascular complications (e.g., nephropathy) (Rabbani and Thornalley, 2011), and ensuring sufficient provision should be a focus of therapy. Further, vitamin B1, B6 and B12 support nervous system functions and helps prevent diabetic neuropathies. A lack of folic acid and/or vitamin B12 leads to impaired metabolism of the amino acid methionine and is frequently accompanied by elevated plasma homocysteine concentrations. Elevated homocysteine levels are regarded as an independent risk factor for stroke, heart attack, dementia and macular degeneration. Compared to non-diabetics, diabetics are three to five times more likely to suffer a stroke (Montero et al., 2013).

As coenzymes the $\mathrm{B}$ vitamins play a central role in carbohydrate, protein and lipid metabolism. A diabetic metabolic status is characterized by both higher requirements and increased renal elimination of $B$ vitamins, especially when the diabetes is not well managed. Studies indicate that the majority of type 1 and type 2 diabetics have inadequate supplies of vitamin B1 and impaired thiamine metabolism (Thornalley et al 2007). A tissue-specific vitamin B1 deficiency (e.g., in the kidneys) can increase the risk of vascular complications (e.g., nephropathy) (Rabbani and Thornalley, 2011), and ensuring sufficient provision should be a focus of therapy. Further, vitamin B1, B6 and B12 support nervous system functions and helps prevent diabetic neuropathies. A lack of folic acid and/or vitamin B12 leads to impaired metabolism of the amino acid methionine and is frequently accompanied by elevated plasma homocysteine concentrations. Elevated homocysteine levels are regarded as an independent risk factor for stroke, heart attack, dementia and macular degeneration. Compared to non-diabetics, diabetics are three to five times more likely to suffer a stroke (Montero et al., 2013).

\subsubsection{Minerals}

The role of microelements, zinc and chromium in glycaemic control is difficult to determine, as they are present in minute amounts and their deficiency is not easily assessed. of the minerals, calcium supplementation is frequently advised, particularly after menopause for women (with diabetes), since dietary calcium may not be sufficient, but as for all the other minerals the recommendations are similar to those for the general population. The ADA dietary guidelines recommend the intake of $1.0-1.5 \mathrm{mg}$ /day of calcium to older people to reduce the risk of osteoporosis. Chromium has been encouraged because of its positive metabolic role particularly in type 2 diabetes. Chromium's actions have been attributed to an increase in the number of insulin receptors, increased binding of insulin to the insulin receptor, and increased activation of the insulin receptor in the presence of insulin (Belinda, 2001). Chromium supports the activity of insulin and sensitizes the pancreatic beta cells, promoting the expression of insulin. Chromium deficiency can lead to reduced glucose tolerance and disordered glucose utilization (Anderson, 1998). Studies showed that supplementation with chromium (III) could bring about an improvement in glucose and/or lipid metabolism, in particular in diabetes sufferers with insufficient chromium intake (Kleefstra et al., 2007). A meta-analysis of numerous clinical studies with type-2 diabetes patients revealed that supplementary administration of chromium (III) improved fasting blood sugar, as well as lipid metabolic status (Cefalu et al., 2010).

Citations: Muhammed D, Adebiyi YH, Odey BO, Ibrahim J, Hassan ON, Ugwunnaji PI, and Berinyuy E.B. (2021). Nutritional Management of Diabetes Mellitus: An appraisal of the role of Medicinal plants. AROC in Natural Product Research. 01(01), 001-027 
Magnesium is acknowledged for its role in insulin sensitivity and its deficiency can contribute to carbohydrate intolerance. One extensive epidemiological study showed that the risk for both type 1 and type 2 diabetes mellitus and for metabolic syndrome as diabetes precursor rises as magnesium intake falls. According to a meta-analysis the risk for diabetes was reduced by $15 \%$ per $100 \mathrm{mg}$ of additional magnesium intake (Larsson and Wolk, 2007). However, only when low serum magnesium levels can be established is repletion with magnesium appropriate.

Sodium is the mineral that receives much attention by both the medical profession and the general public (Leonid, 2009). According to the ADA the amount of sodium in the diet should be limited as it helps reduce blood pressure and the tendency to retain fluids. The main source of sodium in the diet is common table salt. However, as natural foods contain the right amount for the body's need, the general consumption of salt is too high and the recommended goal is to reduce sodium intake to $2400 \mathrm{mg}$ or sodium chloride (salt) to $6000 \mathrm{mg} /$ day (Arnoldi, 2004). Snacks, pickles, bacon, sauces, olives, chips and processed foods in general contain too much salt and should be cut down. (Loria et al., 2001)

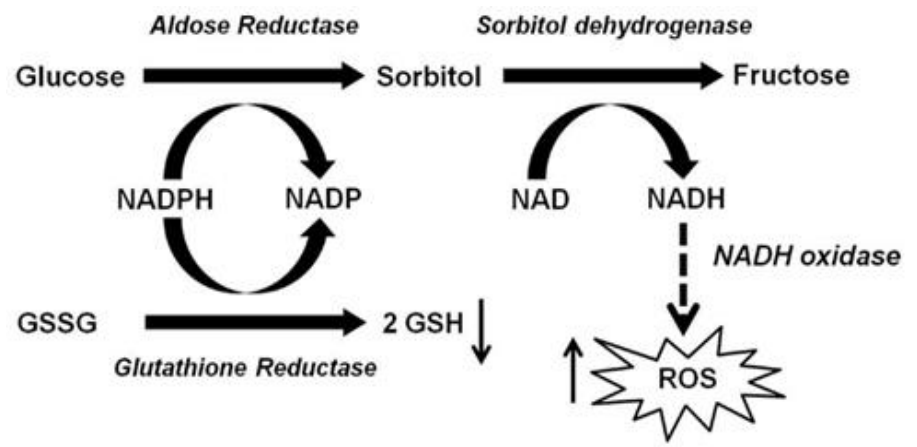

Figure 5: Role of aldose reductase in hyperglycaemia-induced oxidative stress. GSSG-glutathione disulphide, GSHglutathione, ROS - reactive oxygen species

Source: Tang et al., 2012.

Table 1: Classification of glycaemic index

\begin{tabular}{lll}
\hline Class & Gl range (\%) & Examples \\
\hline Low GI & 55 or less & $\begin{array}{l}\text { Beans ( black, white, pink, almond, walnut, peanut), most intact whole } \\
\text { grains ( millet, rice, durum, wheat), fructose, tagatose }\end{array}$ \\
Medium GI & $56-69$ & $\begin{array}{l}\text { Sucrose, banana, unpeeled boiled potato, strawberry, grape, basmati rice. } \\
\text { High GI }\end{array}$ \\
70 and above & $\begin{array}{l}\text { Galactose, maltose, maltodextrin, cornflakes, extruded breakfast meal, } \\
\text { white bread (only wheat endosperm), white rice (only rice endosperm) }\end{array}$
\end{tabular}

Source: Foster-Powell et al., 2002

There is no sufficient information available to justify the recommendation of herbs and supplements for diabetes care. As with the general population, caution should be advised on the use of supplements due to their lack of standardized ingredients and possible drug interactions (American Diabetes Association, 2008).

\subsection{Alcohol Intake}

Type 1 diabetes patients must pay particular attention to alcohol, as it can cause some problems such as lowering blood sugar levels. Otherwise patients with diabetes should take the same precautions as the general population. In fact according to the ADA dietary guidelines (2002), men should have no more than two alcohol-containing drinks per day and no more than one drink for women (there should be no more than 15 $\mathrm{g}$ of alcohol per drink). Alcohol should be drunk at mealtimes and never in exchange for regular food in order to balance calories. Alcohol gives $7 \mathrm{kcal} / \mathrm{g}$, stimulates appetite and also has an adverse effect on self-control, so people with type 2 diabetes should limit their alcohol consumption to special occasions only, especially when on a weight-loss programme (Arnoldi, 2004). Alcohol also increases serum triglyceride 
levels. In certain conditions such as pregnancy or for medical problems such as pancreatitis, neuropathy and severe hypertriglyceridaemia, total abstention is advisable. The use of alcohol is also contraindicated with certain medications, particularly metformin which is frequently prescribed for type 2 diabetes, since alcohol can increase the effects of metformin on lactate metabolism which increases the risk of lactic acidosis (Howard et al., 2004).

\subsection{Dietary Recommendations for Pregnant and Lactating Women}

Nutrients and energy needs increase dramatically during pregnancy and lactation. The time when it is necessary to increase the amount of a specific nutrient varies considerably. Increases in energy needs relate to increased maternal metabolism, added maternal tissues, and growth of the foetus and placenta. Caloric needs during pregnancy may be from 400 to $600 \mathrm{kcal}$ more per day than for the same period in the non-pregnant state (Guthrie and Guthrie, 2009).

Pregnancy is not the time to lose body fat by going on a diet. Calorie restriction is not usually implemented during pregnancy, and there is even controversy about whether women who are obese should gain some weight for optimal fetal development. Restriction of carbohydrates to 35\%$40 \%$ of calories has been shown to decrease maternal glucose levels and improve maternal and foetal outcomes. A gradual, steady weight gain is optimal and is as important as the total weight gained (Reader et al., 2006).

Intakes of nutrients such as protein, iron, folic acid, minerals, and fat-soluble and water-soluble vitamins increase in diabetic pregnant women. The current American nutritional guidelines for diabetic women during pregnancy and lactation are for a daily protein intake of $0.75 \mathrm{~g} / \mathrm{kg}$ plus an additional $10 \mathrm{~g} /$ day (American Diabetes Association, 2004). Protein needs to be increased to assist with growth, particularly of the maternal breasts, uterus, extracellular fluid, and foetus (Guthrie and Guthrie, 2009).

The goals of dietary management in pregnancy include meeting nutritional requirements while eliminating hyperglycaemia. Distribution of meals and snacks must coincide with peaks of insulin given by injection. Because of nausea and hyperemesis in early pregnancy, the size of snacks may begin to equal the size of meals. Three meals and three to four snacks per day with equal timing between periods of food intake are optimal. Eating every 3-4 hour may become necessary to prevent ketonemia. Daily calories of 36-50 kcal $/ \mathrm{kg}$ of ideal body weight should meet a majority of the previously mentioned nutrient needs. This increase may average to about $300 \mathrm{kcal} /$ day above the prepregnancy meal plan. Alcohol consumption during pregnancy is strongly discouraged because of fetal alcohol syndrome (Djelmis et al., 2005).

On a side note, one study found that milk consumption during pregnancy was associated with a higher birth weight for gestational age which correlated with the protein rather than the fat in the milk (Olsen et al., 2007). What probably is more important, at this point, is that women with diabetes who are obese and are pregnant not only beget obesity in their children, but also a tendency for a multitude of complications (Reece, 2008).

Breastfeeding is recommended for women with preexisting diabetes and GDM; however, successful lactation requires planning and coordination of care. Breastfeeding lowers blood glucose, and insulin-treated women may require a carbohydrate-containing snack either before or during breastfeeding. Energy requirements during the first 6 months of lactation are 200 calories in addition to the pregnancy meal plan. However, an energy intake of 1800 kcal/day usually meets the nutritional requirements for lactation and this may allow for a gradual weight loss in overweight type 2 individuals or those who had GDM (Djelmis et al., 2005).

\subsection{Dietary Recommendations for Infant and Young Children}

Dietary recommendations for children with diabetes are based on healthy eating recommendations suitable for all children and adults (National Institute for health and Care Excellence, 2004) and therefore the whole family. Nutritional advice must be adapted to cultural, ethnic and family traditions and the psychosocial needs of the individual child. A specialist pediatric dietician with experience in childhood diabetes should be available as part of a pediatric interdisciplinary diabetes care team to provide education, monitoring and support to the child, parents, careers, extended family, nursery, school teachers, and babysitters. 
There is international agreement that carbohydrate should not be restricted in type 1 diabetes as it may have deleterious effects on growth. Carbohydrate should account for $50-55 \%$ of total daily energy intake. Sucrose and sucrose-containing food should be eaten in the context. For children above 1 year an amount of 2.8-3.4 gms per megajoule is recommended (Smart et al., 2009). Alternatively, for children above 2 years; age in years $+5=$ grams of fiber per day (Williams, 2006) is recommended. Intake of a variety of fiber containing foods such as legumes, fruit, vegetables and wholegrain cereals should be encouraged. Soluble fiber in vegetables, legumes and fruit may be particularly useful in helping to reduce lipid levels (Smart et al., 2009)

Over recent decades surveys have shown children and young people with diabetes consume fat and saturated fat above dietary recommendations (Virtanen et al., 2001) and this situation has not changed (Helgeson et al., 2006; Mayer-Davies et al., 2006; Overby et al., 2007). The intake of total fat, saturated fat, and trans-fatty acids should be decreased (Franz, 2002 a) while Monounsaturated fatty acids (MUFA) and polyunsaturated fatty acids (PUFA) can be used as substitutes to keep lipid intake within recommended ranges or to improve the lipid profile (Franz, $\left.2002^{\mathrm{a}}\right)$.

Total daily energy intake of protein of $10-15 \%$ is recommended. Intake of protein decreases during childhood from approximately $2 \mathrm{~g} / \mathrm{kg} /$ day in early infancy to $1 \mathrm{~g} / \mathrm{kg} /$ day for a ten year old and to $0.8-0.9 \mathrm{~g} / \mathrm{kg} /$ day in later adolescence (Smart et al., 2009). Sources of vegetable protein such as legumes should be encouraged. Sources of animal protein also recommended include fish, lean cuts of meat and low fat dairy products (Smart et al., 2009).

Children with diabetes have the same vitamin and mineral requirements as other healthy children (Smart et al., 2009). Optimum vitamin, mineral and antioxidant intake should be maintained for general health and cardiovascular protection. Many fresh fruits and vegetables are naturally rich in antioxidants (tocopherols, carotenoids, vitamin C, and flavonoids) and are strongly recommended for young people with diabetes. Supplements of vitamins, minerals or trace elements are not usually recommended unless nutritional assessment confirms a specific deficiency. Supplements such as vitamin D for young children are recommended in some countries following the national guidelines for healthy children (Franz, 2002a).

\subsection{Appraisal of the role of Medicinal plants in treatment of diabetes}

Medicinal plants play a significant role in the treatment of several diseases and have been reported to be safe for use as oral remedy (Bashir et al., 2015, Lawal et al., 2015, Lawal et al., 2016, Lawal et al., 2017, Yusuf et al., 2018a, 2018b, Umar et al., 2019, Yusuf et al., 2020, Adeshina et al., 2020). Traditional plants are reported to have significant antidiabetic properties with no harmful side effects. They are rich sources of anti-diabetic compounds such as flavonoids, alkaloids, phenolic and tannins that improve the efficiency of pancreatic tissues by increasing the insulin secretion or decreasing the intestinal absorption of glucose (Bindu \& Narendhirakannan, 2019; Kooti et al. 2016)

Literature suggests that there are approximately 410 experimentally proven medicinal plants with anti-diabetic properties out of which the complete mechanism has been studied only for 109 plants. Several medicinal plant extracts have been shown to modulate the metabolic pathways such as glycolysis, gluconeogenesis, Krebs cycle, glycogen synthesis and their degradation, synthesis and release of insulin, cholesterol synthesis, carbohydrate metabolism and absorption (Prabhakar and Doble 2008).

We presented the list of medicinal plants that are known to possess anti-diabetic properties. These plants are traditionally used by various tribal people for the treatment of several ailments. Pharmacological studies have reported their hypoglycemic, anti-hyperglycemic, insulin mimicking, anti-lipidemic properties and hence when administered in proper dosages can be beneficial for ameliorating the various complications associated with diabetes mellitus (Bindu \& Narendhirakannan, 2019) 
Table 2: Medicinal plants with anti-diabetic properties

Adapted from Bindu \& Narendhirakannan (2019).

\begin{tabular}{|c|c|c|c|c|c|}
\hline $\begin{array}{ll}\text { S. } \\
\text { no. }\end{array}$ & Botanical name & $\begin{array}{l}\text { Common } \\
\text { name(s) }\end{array}$ & Family & $\begin{array}{l}\text { Part(s) used } \\
\text { for the study }\end{array}$ & Activities \\
\hline 1 & $\begin{array}{l}\text { Abelmoschus } \\
\text { esculentus (L.) Moench }\end{array}$ & Lady's finger & Malvaceae & Seeds, fruit & $\begin{array}{l}\text { Antidiabetic, antioxidant } \\
\text { and antihyperlipidemic }\end{array}$ \\
\hline 2 & Acacia nilotica (L.) Delile & $\begin{array}{l}\text { Gum arabic } \\
\text { tree }\end{array}$ & Leguminosae & Leaves & $\begin{array}{l}\text { Antioxidant, antidiabetic, } \\
\text { antihyperlipidemic }\end{array}$ \\
\hline 3 & Allium cepa L. & Onion & Amaryllidaceae & Bulb & $\begin{array}{l}\text { Hypoglycemic, anti- } \\
\text { diabetic, anti- } \\
\text { hyperlipidemic }\end{array}$ \\
\hline 4 & Aloe vera (L.) Burm.f. & Aloe & Asphodelaceae & Leaves & $\begin{array}{l}\text { Anti-hyperglycemic. anti- } \\
\text { hypercholesterolemic, } \\
\text { hypoglycemic, } \\
\text { hypolipidemic }\end{array}$ \\
\hline 5 & Annona squamosa L. & Sugar apple & Annonaceae & $\begin{array}{l}\text { Leaves, fruit } \\
\text { pulp }\end{array}$ & $\begin{array}{l}\text { Hypoglycemic, anti- } \\
\text { diabetic, anti-lipidemic }\end{array}$ \\
\hline 6 & $\begin{array}{l}\text { Artemisia pallens Wall. } \\
\text { ex DC. }\end{array}$ & Artemisia & Asteraceae & Aerial parts & Hypoglycemic \\
\hline 7 & Averrhoa bilimbi L. & Bilimbi & Oxalidaceae & $\begin{array}{l}\text { Leaves, roots, } \\
\text { fruit }\end{array}$ & $\begin{array}{c}\text { Anti-hyperglycemic, anti- } \\
\text { hyperlipidemic, } \\
\text { hypoglycemic, anti- } \\
\text { diabetic }\end{array}$ \\
\hline 8 & $\begin{array}{l}\text { Azadirachta indica A. } \\
\text { Juss }\end{array}$ & Neem tree & Meliaceae & Leaves, seeds & $\begin{array}{l}\text { Hypoglycemic, } \beta \text {-cell } \\
\text { regeneration }\end{array}$ \\
\hline 9 & Berberis vulgaris L. & Barberry & Berberidaceae & Root, fruit & $\begin{array}{l}\text { Hypoglycemic, anti- } \\
\text { diabetic }\end{array}$ \\
\hline 10 & Beta vulgaris L. & Beet & Amaranthaceae & Leaves, fruit & $\begin{array}{l}\text { Anti-hyperglycemic, } \\
\text { hypoglycemic }\end{array}$ \\
\hline 11 & $\begin{array}{l}\text { Biophytum } \\
\text { sensitivum (L.) DC. }\end{array}$ & $\begin{array}{l}\text { Little tree } \\
\text { plant }\end{array}$ & Oxalidaceae & Leaves & Hypoglycemic \\
\hline 12 & $\begin{array}{l}\text { Brassica juncea (L.) } \\
\text { Czern. }\end{array}$ & $\begin{array}{l}\text { Brown } \\
\text { mustard }\end{array}$ & Brassicaceae & Seeds & Hypoglycemic \\
\hline 13 & $\begin{array}{l}\text { Bryophyllum } \\
\text { pinnatum (Lam.) Oken }\end{array}$ & $\begin{array}{l}\text { Life plant, } \\
\text { miracle leaf }\end{array}$ & Crassulaceae & Leaves & Antidiabetic, hypoglycemic \\
\hline 14 & Boerhavia diffusa L. & $\begin{array}{l}\text { Spreading } \\
\text { hogweed }\end{array}$ & Nyctaginaceae & Leaves & Anti-diabetic \\
\hline 15 & Bombax ceiba L & Cotton tree & Bombacaceae & Leaves & $\begin{array}{l}\text { Antihyperglycemic, } \\
\text { antihyperlipidemic }\end{array}$ \\
\hline 16 & $\begin{array}{l}\text { Caesalpinia bonduc (L.) } \\
\text { Roxb }\end{array}$ & Fever nut & Caesalpiniaceae & $\begin{array}{l}\text { Seeds, root } \\
\text { bark }\end{array}$ & $\begin{array}{c}\text { antihyperglycemic, } \\
\text { antihypercholesterolemic, } \\
\text { antihypertriglyceridemic } \\
\text { hypolipidemic }\end{array}$ \\
\hline 17 & Cajanus cajan (L.) Millsp. & Pigeon pea & Fabaceae & Leaves, seeds & Hypoglycemic \\
\hline 18 & $\begin{array}{l}\text { Camellia sinensis (L.) } \\
\text { Kuntze }\end{array}$ & Tea plant & Theaceae & Leaves & $\begin{array}{l}\text { Anti-hyperglycemic, } \\
\text { antihyperglycemic and }\end{array}$ \\
\hline
\end{tabular}




\begin{tabular}{|c|c|c|c|c|c|}
\hline 19 & $\begin{array}{l}\text { Capparis } \\
\text { decidua (Forssk.) Edgew. }\end{array}$ & Karira & Capparidaceae & $\begin{array}{l}\text { Fruit, flowers, } \\
\text { bark }\end{array}$ & $\begin{array}{l}\text { Anti-diabetic, } \\
\text { hypolipidemic }\end{array}$ \\
\hline 20 & Capsicum annuum L. & Capsicum & Solanaceae & Fruit & Insulinotropic \\
\hline 21 & $\begin{array}{l}\text { Centaurium } \\
\text { erythraea Rafn }\end{array}$ & $\begin{array}{l}\text { Common } \\
\text { centaury }\end{array}$ & Gentianaceae & Leaves & Antihyperglycemic \\
\hline 22 & $\begin{array}{l}\text { Catharanthus roseus (L.) } \\
\text { G.Don }\end{array}$ & $\begin{array}{l}\text { Madagascar } \\
\text { periwinkle }\end{array}$ & Apocynaceae & Leaves & $\begin{array}{c}\text { Anti-diabetic, } \\
\text { hyperlipidemic, anti- } \\
\text { hyperglycemic }\end{array}$ \\
\hline 23 & $\begin{array}{l}\text { Citrullus colocynthis (L.) } \\
\text { Schrad. }\end{array}$ & $\begin{array}{l}\text { Bitter apple, } \\
\text { wild gourd }\end{array}$ & Cucurbitaceae & $\begin{array}{l}\text { Fruit, seeds, } \\
\text { root }\end{array}$ & $\begin{array}{c}\text { Hypoglycemic, } \\
\text { antihyperglycemic }\end{array}$ \\
\hline 24 & $\begin{array}{l}\text { Clausena anisata (Willd.) } \\
\text { Hook.f. ex Benth. }\end{array}$ & Horsewood & Rutaceae & Root & Hypoglycemic \\
\hline 25 & Cocos nucifera L. & Coconut & Arecaceae & $\begin{array}{l}\text { Spadix, drupe, } \\
\text { coconut water }\end{array}$ & $\begin{array}{l}\text { Anti-hyperglycemic, } \\
\text { antiglycation, } \\
\text { hypoglycemic }\end{array}$ \\
\hline 26 & $\begin{array}{l}\text { Cheilocostus } \\
\text { speciosus (J.Koenig) } \\
\text { C.D.Specht }\end{array}$ & Cane-reed & Costaceae & Root, leaves & $\begin{array}{l}\text { Antihyperglycemic, } \\
\text { hypoglycemic, } \\
\text { hypolipidemic }\end{array}$ \\
\hline 27 & Curcuma longa L. & Turmeric & Zingiberaceae & Rhizome & $\begin{array}{l}\text { Antioxidant, antidiabetic, } \\
\text { hepatoprotective }\end{array}$ \\
\hline 28 & $\begin{array}{l}\text { Cyclocarya } \\
\text { paliurus (Batalin) Iljinsk. }\end{array}$ & $\begin{array}{l}\text { Wheel } \\
\text { wingnut }\end{array}$ & Juglandaceae & Bark & $\begin{array}{l}\text { Hypoglycemic, anti-ti- } \\
\text { hyperglycemic, anti- } \\
\text { hyperlipidemic }\end{array}$ \\
\hline 29 & Dillenia indica L. & $\begin{array}{l}\text { Elephant } \\
\text { apple }\end{array}$ & Dilleniaceae & Leaves & $\begin{array}{c}\text { Antidiabetic, } \\
\text { hypolipidemic }\end{array}$ \\
\hline 30 & $\begin{array}{l}\text { Eucalyptus } \\
\text { globulus Labill. }\end{array}$ & Blue-gum & Myrtaceae & Leaves & Anti-hyperglycemic \\
\hline 31 & Embelia ribes Burm.f. & $\begin{array}{l}\text { False black } \\
\text { pepper }\end{array}$ & Myrsinaceae & Berries & $\begin{array}{c}\text { Anti-hyperglycemic, anti- } \\
\text { diabetic }\end{array}$ \\
\hline 32 & Eugenia uniflora L. & $\begin{array}{l}\text { Brazilian } \\
\text { cherry }\end{array}$ & Myrtaceae & Fruit & $\begin{array}{l}\text { Antihyperglycemic, } \\
\text { antidyslipidemic }\end{array}$ \\
\hline 33 & Ficus benghalensis L. & Banyan tree & Moraceae & $\begin{array}{l}\text { Bark, aerial } \\
\text { roots }\end{array}$ & Anti-diabetic \\
\hline 34 & Ficus religiosa L. & Sacred fig & Moraceae & Bark & Anti-diabetic \\
\hline 35 & Helicteres isora L. & $\begin{array}{l}\text { Indian screw } \\
\text { tree }\end{array}$ & Sterculiaceae & Root & $\begin{array}{c}\text { Antidiabetic, } \\
\text { hypolipidemic, } \\
\text { antihyperglycemic }\end{array}$ \\
\hline 36 & Hibiscus rosa-sinensis L. & $\begin{array}{l}\text { Chinese } \\
\text { hibiscus, shoe } \\
\text { black plant }\end{array}$ & Malvaceae & Flower, leaves & $\begin{array}{l}\text { Hypoglycemic, } \\
\text { antidyslipidemic }\end{array}$ \\
\hline 37 & $\begin{array}{l}\text { Ipomoea batatas (L.) } \\
\text { Lam }\end{array}$ & Sweet potato & Convolvulaceae & Leaves, root & Hypoglycemic \\
\hline 38 & Juniperus communis L. & $\begin{array}{l}\text { Common } \\
\text { juniper }\end{array}$ & Cupressaceae & Berries & Hypoglycemic \\
\hline 39 & Lantana camara L. & $\begin{array}{l}\text { Big-sage, wild- } \\
\text { sage }\end{array}$ & Verbenaceae & Fruits & $\begin{array}{c}\text { Anti-hyperglycemic, anti- } \\
\text { diabetic }\end{array}$ \\
\hline 40 & $\begin{array}{l}\text { Lithocarpus } \\
\text { polystachyus (Wall. ex }\end{array}$ & Sweet tea & Fagaceae & Leaves & Hypoglycemic \\
\hline
\end{tabular}

Citations: Muhammed D, Adebiyi YH, Odey BO, Ibrahim J, Hassan ON, Ugwunnaji PI, and Berinyuy E.B. (2021). Nutritional Management of Diabetes Mellitus: An appraisal of the role of Medicinal plants. AROC in Natural Product Research. 01(01), 001-027 


\begin{tabular}{|c|c|c|c|c|c|}
\hline 41 & $\begin{array}{l}\text { A.DC.) Rehder } \\
\text { Phyla nodiflora (L.) } \\
\text { Greene }\end{array}$ & Capeweed & Verbenaceae & Whole plant & $\begin{array}{l}\text { Anti-hyperlipidemic, anti- } \\
\text { hyperglycemic }\end{array}$ \\
\hline 42 & Mangifera indica L. & Mango & Anacardiaceae & Leaves, fruit & $\begin{array}{l}\text { Anti-diabetic, } \\
\text { hypoglycemic }\end{array}$ \\
\hline 43 & $\begin{array}{l}\text { Memecylon } \\
\text { umbellatum Burm. f. }\end{array}$ & Iron wood & Melastomataceae & Leaves & Anti-diabetic \\
\hline 44 & Morus alba L. & $\begin{array}{l}\text { White } \\
\text { mulberry }\end{array}$ & Moraceae & Fruit, leaves & $\begin{array}{l}\text { Anti-hyperglycemic, anti- } \\
\text { hyperlipidemic, anti- } \\
\text { glycemic }\end{array}$ \\
\hline 45 & $\begin{array}{l}\text { Mucuna pruriens (L.) } \\
\text { DC. }\end{array}$ & Velvet bean & Fabaceae & Seeds & Anti-diabetic \\
\hline 46 & Musa $\times$ paradisiaca $\mathrm{L}$. & Plantain & Musaceae & $\begin{array}{l}\text { Stem, leaves, } \\
\text { infructescence } \\
\text { stalks, fruit }\end{array}$ & $\begin{array}{c}\text { Antidiabetic, } \\
\text { antihyperlipidemic, anti- } \\
\text { hyperglycemic }\end{array}$ \\
\hline 47 & $\begin{array}{l}\text { Nelumbo } \\
\text { nucifera Gaertn. }\end{array}$ & Indian lotus & Nelumbonacea & Seeds, leaves & $\begin{array}{c}\text { Hypoglycemic, } \\
\text { antihyperlipidemic }\end{array}$ \\
\hline 48 & Olea europaea L. & Wild olive & Oleaceae & Leaves & $\begin{array}{l}\text { Antihyperglycemic, } \\
\text { hypolipidemic, } \\
\text { hypoglycemic }\end{array}$ \\
\hline 49 & $\begin{array}{l}\text { Ophiopogon } \\
\text { japonicus (Thunb.) Ker } \\
\text { Gawl. }\end{array}$ & Dwarf lilyturf & Asparagaceae & Root & $\begin{array}{l}\text { Anti-diabetic, } \\
\text { hypoglycemic }\end{array}$ \\
\hline 50 & $\begin{array}{l}\text { Opuntia } \\
\text { streptacantha Lem. }\end{array}$ & $\begin{array}{l}\text { Prickly pear } \\
\text { cactus }\end{array}$ & Cactaceae & $\begin{array}{l}\text { Leaves } \\
\text { (cladode) }\end{array}$ & Anti-hyperglycemic \\
\hline 51 & Phyllanthus niruri L. & Stonebreaker & Phyllanthaceae & Aerial parts & Anti-diabetic \\
\hline 52 & $\begin{array}{l}\text { Picrorhiza kurroa Royle } \\
\text { ex Benth. }\end{array}$ & Yellow gentian & Plantaginaceae & Rhizome & Anti-diabetic \\
\hline 53 & Piper nigrum L. & Black pepper & Piperaceae & Fruit & Anti-hyperglycemic \\
\hline 54 & $\begin{array}{l}\text { Prosopis } \\
\text { glandulosa Torr. }\end{array}$ & $\begin{array}{l}\text { Honey } \\
\text { mesquite }\end{array}$ & Fabaceae & Pods & Anti-diabetic \\
\hline 55 & Psidium guajava L. & Guava & Myrtaceae & Fruit, leaves & $\begin{array}{l}\text { Anti-hyperglycemic, anti- } \\
\text { hyperlipidemic }\end{array}$ \\
\hline 56 & $\begin{array}{l}\text { Pterocarpus } \\
\text { marsupium Roxb. }\end{array}$ & $\begin{array}{l}\text { Indian kino } \\
\text { tree }\end{array}$ & Fabaceae & Bark & $\begin{array}{c}\text { Hypoglycemic, anti- } \\
\text { hyperglycemic, inhibition } \\
\text { of aldose reductase activity }\end{array}$ \\
\hline 57 & Punica granatum L. & Pomegranate & Punicaceae & Leaves, fruit & $\begin{array}{l}\text { Anti-diabetic, anti- } \\
\text { hyperlipidemic, anti- } \\
\text { glycation }\end{array}$ \\
\hline 58 & Salacia reticulata Wight & $\begin{array}{l}\text { Marking nut } \\
\text { tree, } \\
\text { kotalahimbatu }\end{array}$ & Celastraceae & $\begin{array}{l}\text { Root, stem, } \\
\text { leaves }\end{array}$ & $\begin{array}{l}\text { Anti-diabetic, anti- } \\
\text { hyperlipidemic }\end{array}$ \\
\hline 59 & $\begin{array}{l}\text { Semecarpus } \\
\text { anacardium L.f. }\end{array}$ & Marking nut & Anacardiaceae & Nut & $\begin{array}{l}\text { Anti-hyperlipidemic, } \\
\text { hypoglycemic and } \\
\text { antihyperglycemic }\end{array}$ \\
\hline 60 & $\begin{array}{l}\text { Senna auriculata (L.) } \\
\text { Roxb. }\end{array}$ & $\begin{array}{l}\text { Avaram senna, } \\
\text { styptic weed, } \\
\text { Matara tea }\end{array}$ & Fabaceae & Leaves, flower & $\begin{array}{l}\text { Antihyperglycemic, } \\
\text { hypolipidemic, } \\
\text { antihyperlipidemic }\end{array}$ \\
\hline 61 & Solanum virginianum $\mathrm{L}$. & Yellow-fruit & Solanaceae & Leaves & Anti-hyperglycemic \\
\hline
\end{tabular}

Citations: Muhammed D, Adebiyi YH, Odey BO, Ibrahim J, Hassan ON, Ugwunnaji PI, and Berinyuy E.B. (2021). Nutritional Management of Diabetes Mellitus: An appraisal of the role of Medicinal plants. AROC in Natural Product Research. 01(01), 001-027 


\begin{tabular}{|c|c|c|c|c|c|}
\hline 62 & $\begin{array}{l}\text { Swertia chirayita (Roxb.) } \\
\text { Buch.-Ham. ex C.B.Clarke }\end{array}$ & $\begin{array}{l}\text { nightshade } \\
\text { Clearing nut } \\
\text { tree, bitter } \\
\text { stick }\end{array}$ & Gentianaceae & Whole plant & Anti-diabetic \\
\hline 63 & $\begin{array}{l}\text { Symplocos } \\
\text { cochinchinensis (Lour.) } \\
\text { S. Moore }\end{array}$ & $\begin{array}{l}\text { Laurel } \\
\text { sapphire berry }\end{array}$ & Symplocaceae & Leaves & $\begin{array}{l}\text { Anti-diabetic, anti- } \\
\text { lipidemic }\end{array}$ \\
\hline 64 & $\begin{array}{l}\text { Tetraena alba (L.f.) Beier } \\
\text { \& Thulin }\end{array}$ & $\begin{array}{l}\text { White bean- } \\
\text { caper }\end{array}$ & Zygophyllaceae & Whole plant & $\begin{array}{l}\text { Antihyperglycemic and } \\
\text { antihyperlipidemic }\end{array}$ \\
\hline 65 & $\begin{array}{l}\text { Tinospora } \\
\text { sinensis (Lour.) Merr. }\end{array}$ & $\begin{array}{l}\text { Malabar } \\
\text { gulbel, } \\
\text { Chinese } \\
\text { tinospora }\end{array}$ & Menispermaceae & Root & $\begin{array}{l}\text { Hypoglycemic and } \\
\text { hypolipidemic }\end{array}$ \\
\hline 66 & $\begin{array}{l}\text { Trigonella foenum- } \\
\text { graecum L. }\end{array}$ & Fenugreek & Fabaceae & Seeds & $\begin{array}{c}\text { Hypoglycemic, } \\
\text { hypocholesterolemic, anti- } \\
\text { hyperglycemic }\end{array}$ \\
\hline 67 & Urtica dioica $\mathrm{L}$ & $\begin{array}{l}\text { Stinging nettle } \\
\text { Chinese }\end{array}$ & Urticaceae & Aerial parts & Anti-hyperglycemic \\
\hline 68 & Vitex negundo L. & $\begin{array}{l}\text { chastetree, } \\
\text { horseshoe } \\
\text { vitex }\end{array}$ & Lamiaceae & Leaves & Anti-hyperglycemic \\
\hline 69 & Viscum album L. & Mistletoe & Viscaceae & Leaves & $\begin{array}{l}\text { Antihyperglycemic, } \\
\text { insulinotropic }\end{array}$ \\
\hline
\end{tabular}

\section{Conclusion and Future Perspective}

The enormous economic, social and personal cost of management of diabetes makes a compelling case for prevention. In recent years, there has been much new evidence demonstrating the potentially preventable and manageable nature of diabetes, particularly by the implementation of nutritional modification. In view of this and the devastating health impact of the disease it seems prudent that primary prevention and management should be a major priority. Since the 1970s there have been numerous healths promotion projects that have attempted to encourage diabetic's patients to lead a healthier lifestyle (Steyn et al., 2004). Nutrition education and lifestyle counseling should be adapted to individual needs and delivered in a patient-centered manner. Education can be delivered both to the individual child and family and in small group settings (National Institute for health and Care Excellence 2004).

In order to achieve maximum benefit from nutritional interventions in managements of diabetes changes in government policies and legislation will be needed in addition to individual and community-based programmes. This would include mandating more nutrition education in schools, banning the advertising of unhealthy products and subsidising healthy foods at the expense of less appropriate foods. Despite much research on nutritional factors in the aetiology and management of diabetes, the risk associated with several individual nutrients is not entirely clear. Therefore, there is an urgent need for more research and rigorous evaluation of dietetic management in diabetes mellitus. In making recommendations to the public regarding the prevention of diabetes, priority should be given to the following; consumption of a nutrient-dense diet, which is low in fat, particularly saturated fat, and free sugars and high in non-starch polysaccharides (Vessby et al., 2001). Also, nutritional management should be coupled with physical activities and in the case of type 1 diabetes, insulin doses need to be adjusted to balance with nutritionally adequate food intake.

Advancement in modern medicine has resulted in the development of several pharmaceutical drugs such as biguanides, thiazolidinediones, biguanides, and insulin. 
Even though these drugs show hypoglycemic activities, they are often associated with several complications such as nephrological disorders, fatigue, upset stomach, diarrhea, etc. All these reasons have stimulated the rework on herbal medicine to fine suitable alternatives that will have lesser side effects and improved therapeutic effects. The present review has summarized the list of medicinal plants that are known to possess anti-diabetic properties. These plants are traditionally used by various tribal people for the treatment of several ailments. Pharmacological studies have reported their hypoglycemic, anti-hyperglycemic, insulin mimicking, anti-lipidemic properties and hence when administered in proper dosages can be beneficial for ameliorating the various complications associated with diabetes mellitus. This review provides the scope for the readers to further explore the active constituents of anti-diabetic plants and its possible mechanisms for future research.

\section{REFERENCES}

Adesina, D.A., S.F. Adefolalu, A.A. Jigam and B. Lawal, (2020). Antiplasmodial effect and sub-acute toxicity of alkaloid, flavonoid and phenolic extracts of Sida acuta leaf on Plasmodium berghei-infected animals. J. Taibah Uni. Sci., 14: 943-953.

Alice, 0., and Fred, 0. (2013). The modern nutritional diseases and how to prevent them ( $2^{\text {nd }}$ edition).

American Diabetes Association (2000).Scope of Practice for Diabetes.DiabetesCare 26:25-31.

American Diabetes Association (2002). Evidence based nutrition principles and recommendations for the treatment and prevention of diabetes and related complications. Diabetes Care .25(suppl):S50-60.

American Diabetes Association (2008). Nutrition recommendations and principles for people with diabetes mellitus.Diabetes Care. 31(Suppl 1):S61-S77.

American Diabetes Association (2011). Standards of Medical Care in Diabetes.Diabetes Care 34: S11-61.

American Diabetes Association (2016). Retrieved from www.diabetes.org $>$ diabetesbasics $>$ diagnosis on February, $3^{\text {rd }} 2017$.
American Diabetes Association: Position statement: Nutrition principles and recommendations indiabetes. DiabetesCare.27:S36.

Anderson, R. A. (1998).Chromium, Glucose Intolerance and Diabetes. Journal of the American College of Nutrition. 17:548-555.

Arnoldi, A. (2004). Functional Foods, Cardiovascular Disease and Diabetes. New York: Woodhead Publishing Limited. pp. 130-140.

Bashir, L., O.K. Shittu, S. Sani, M.B. Busari and K.A. Adeniyi, 2015. African natural products with potential antitrypanosomal properties: A review. Int. J. Biochem. Res. Rev., 7: 45-79.

Baynes, H.W. (2015). Classification, Pathophysiology, Diagnosis and Management of Diabetes Mellitus. Journal of Diabetes and Metabolism, 6: 541

Belinda, R. (2004). Gale Encyclopaedia of Alternative Medicine. pp 2603-2605.

Belinda, S.O. (2001): Select Vitamins and Minerals in the Management of Diabetes. Diabetes spectrum, 14(3):133-148

Berg, J., Tymoczko, J.L., and Stryer, L. (2002). Biochemistry (5th ed.). San Francisco: W.H. Freeman. pp. 603.

Berry, E.M., Eisenberg, S., and Haratz, D. (1991). Effects of Diets Rich in Monounsaturated Fatty Acids on Plasma Lipoproteins - the Jerusalem Nutrition study: high MUFAs vs high PUFAs. American Journal of Clinical Nutrition; 53: 899-907.

Bindu Jacob, \& Narendhirakannan R T (2019). Role of medicinal plants in the management of diabetes mellitus: a review. 3 Biotech, 9(1), 4. https://doi.org/10.1007/s13205-018-1528-0

Bjornholm, M. and Zierath, J. (2005). Insulin Signal Transduction in Human Skeletal Muscle: Identifying the Defects in Type 2 Diabetes. Biochemical Society Transaction, 33(2): 354-357. 
Cefalu, W., Rood, J., Pinsonat, P., Qin J., Sereda, O., and Levitan, L. (2010). Characterization of the Metabolic and Physiologic Response to Chromium Supplementation in Subjects with Type 2 Diabetes Mellitus. Metabolism, 59(5):755-762.

Chan, J.C., Malik, V., and Jia, W. (2009). Diabetes in Asia; Epidemiology, Risk Factors, and Pathophysiology. The Journal of the American Medical Association, 301:21292140.

Clavel, C.M. (2005). Mayo Clinic on Managing Diabetes. New York: Kensington Publishing Corporation. Retrived on October, 2016.

Cunningham J., Mearkle, P., and Brown R. (1994). Vitamin C: An Aldose Reductase Inhibitor that Normalizes Erythrocyte Sorbitol in Insulin-dependent Diabetes Mellitus, Journal of the American College of Nutrition, 13:344-350.

Dakhale, G. N., Chaudhari, H., and Shrivastava, M. (2011). Supplementation of Vitamin C Reduces Blood Glucose and Improves Glycosylated Hemoglobin in Type 2 Diabetes Mellitus: A Randomized, Double-blind Study. Advances in Pharmacological Science, 9:52-65

Davidson, M.B., Mathur, R. and Harmel, A.P. (2003). Davidson's Diabetes Mellitus -Diagnosis and treatment $\left(5^{\text {th }}\right.$ ed.), Churchhill Livingston inc USA. pp. 236-300.

Diabetes Prevention Program Research Group (2009). 10year follow-up of diabetes incidence and weight loss in Prevention Program Outcomes Study. Lancet, 374(9702):1677-1686.

Djelmis, J., Desoye, G., and Ivanisevic, M. (2005): Diabetology of Pregnancy. Frontiers in Diabetes, 17:174194

European Diabetes Policy Group (1999). A Desktop Guide to Type 2 Diabetes Mellitus. Diabetic Medicine, 16: 716-730.

Felig, P. (2005). Amino Acid Metabolism in Man. Annual Review Biochemistry, 44: 933-955.
Foster-Powell, K., Holt S.H., Brand-Miller, J.C. (2002). International Table of Glycaemic Index and Glycaemic Load Values. American Journal of Clinical Nutrition, 76(1):5-56

Franz, M.J. (2002a). Evidence-based Nutrition Principles and Recommendations for the Treatment and Prevention of Diabetes and Related Complications. Technical review Diabetes Care, 25: 48-198.

Franz, M.J. (2002b). Protein and Diabetes: Much Advice, Little Research. Current DiabetesReport, 2: 457-464.

Fuhrman, J. (2014). The End of Dieting. Harper Collins. pp. 101-102.

Gillett, M.J. (2009). International Expert Committee Report on the Role of the A1c Assay in the Diagnosis of Diabetes: Diabetes Care, 32(7): 1327-1334.

Gokhale, N, Acharya, A, Patil, V., Trivedi, D., and Thakur, S. A. (2013). Short-term Evaluation of the Relationship Between Plasma Ascorbic Acid Levels and Periodontal Disease in Systemically Healthy and Type 2 Diabetes Mellitus Subjects. Journal of Dietary Supplements, 10(2):93-104.

González, E.L., Johansson, S., Wallander, M.A., and Rodríguez, L.A. (2009). Trends in the Prevalence and Incidence of Diabetes in the UK: 1996 - 2005. Journal of Epidemiology and Community Health, 63: 332-336.

Guettier, J.M. and Gorden, P. (2006). Hypoglycaemia. Endocrinology and Metabolism Clinics of North America, 35(4):753-766.

Guthrie, D. and Guthrie, R. (2009). Management of Diabetes Mellitus: A Guide to Pattern Approach. $6^{\text {th }}$ Edition: pp287288

Helgeson, V.S., Viccaro, L., Becker, D., Escobar, O., and Siminerio, L. (2006). Diet of Adolescents with and without Diabetes. Diabetes Care. 29: 982-987.

Holt, G. I. (2004). Diagnosis, Epidemiology and Pathogenesis of Diabetes Mellitus: An Update for Psychiatrists. British Journal of Psychiatry, 184:s55- s63. 
Howard, A.A., Arnsten, J.H.,and Gourevitch, M.N. (2004). Effect of Alcohol Consumption on Diabetes Mellitus: A Systemic Review. Annuals of Internal Medicine, 140:211219.

Iwueze, J.O. (2007). Managing your Diabetes: Assessment and Management of Patients with Diabetes Mellitus.Owerri: Skillmark Media Ltd. p. 42

Jeffrey, S. F. (2006). Regulating Energy Balance: The Substrate Strike Back. Science, 861

John, G.V., Catherine, G., and Barbara, N. (2009). The New Oxford Book Of Food Plants. Oxford University Press US. pp. 212.Retrieved 13 October 2016.

Kaku, K. (2010). Pathophysiology of Type 2 Diabetes and its Treatment Policy. The Journal of the American Medical Association,53(1):41-46.

Kibiti, C.M. (2006). Hypoglycaemic Potential of some Kenyan Plants used in Traditional Medicine in Rift Valley, Nairobi and Eastern Provinces, Msc Thesis, Kenyatta University.

Kleefstra, N., Houweling, S., and Bilo, H. (2007). Effect of Chromium Supplementation on Glucose Metabolism and Lipids: A Systematic Review of Randomized Controlled Trials. Diabetes Care, 30:2154-2163.

Kooti W, Farokhipour M, Asadzadeh Z, Ashtary-Larky D, Asadi-Samani M. The role of medicinal plants in the treatment of diabetes: a systematic review. Electron Physician. 2016;8(1):1832-1842. doi: 10.19082/1832

KrishnaDas, K.V (2008). Textboook of Medicine (5 ${ }^{\text {th }}$ edition).

Kumar, P.J., and Clark, M. (2002). Textbook of Clinical Medicine. Pub: Saunders, London, UK. pp 1099-1121.

Larsson, S. C. and Wolk, A. (2007). Magnesium Intake and Risk of Type 2 Diabetes: A Meta-analysis. Journal of Internal Medicine, 262:208-214.

Lawal, B., O.K. Shittu, A.Y. Kabiru, A.A. Jigam, M.B. Umar, E.B. Berinyuy and B.U. Alozieuwa, (2015). Potential antimalarials from African natural products: A review. J. Intercultural Ethnopharmacol., $\quad 4: \quad 318-343$.

Lawal, B., O.K. Shittu, F.I. Oibiokpa, E.B. Berinyuy and H. Mohammed, (2017). African natural products with potential antioxidants and hepatoprotectives properties: A review. Clin. Phytosci., Vol. 2, No. 1. 10.1186/s40816-0160037-0.

Lawal, B., O.K. Shittu, I.F. Oibiokpa, H. Mohammed, S.I. Umar and G.M. Haruna, (2016). Antimicrobial evaluation, acute and sub-acute toxicity studies of Allium sativum. J. Acute Dis., 5: 296-301.

Leonid, P. (2009). Principles of Diabetes Mellitus (2 $2^{\text {nd }}$ edition). Springer New York Dordrecht Heidelberg London. pp 681-683.

Lichtenstein, A.H., and Deckelbaum, R.J. (2001). Stanol/Sterol Ester-containing Foods and Blood Cholesterol Levels. American Heart Association Circulation, 103:11771179.

Liese, A.D., Schulz, M., and Fang, F. (2005). Dietary Glycaemic Index and Glycaemic Load, Carbohydrate and Fiber Intake, and Measures of Insulin Sensitivity, Secretion, and Adiposity in the Insulin Resistance Atherosclerosis Study. Diabetes Care, 28:2832-2838.

Loria, C.M., Obarzanek, E., and Ernst, N. (2001). Choose and Prepare Foods with Less Salt: Dietary Advice for all. American Journals of Nutrition, 131:536S-551S.

Manninen, A. H. (2002). Protein Metabolism in Exercising Humans with Special Reference to Protein Supplementation.Opinnäytetutkielma 164 sivua

Mathews, C.K., Van, K.E., and Ahern, K.G. (2000). Biochemistry. San Francisco, CA: Benjamin/Cummings

Mayer-Davies, E.J., Nichols, M., Liese, A.D. (2006). Dietary Intake Among Youth with Diabetes: The Search for Diabetes in Youth Study. Journal of American Dietetic Association, 106: 689-697. 
Mayo foundation for medical education and research (2016). Retrieved on February $3^{\text {rd }} 2017$.

Mazloom, Z., Ekramzadeh, M., and Hejazi, N. (2013). Efficacy of Supplementary Vitamins C and E on Anxiety, Depression and Stress in Type 2 Diabetic Patients: A Randomized, Single-blind, Placebo-controlled Trial. Pakistan Journal of Biological Science, 16:1597-1600.

Mealey, B.L. (2006). Diabetes Mellitus Management. Diabetes Mellitus and Oral Health. Armenian Medical Network. Retrieved 2 October 2016.

Meredith M., Qu, Z., and May, J. (2014). Ascorbate Reverses High Glucose- and RAGE-induced Leak of the Endothelial Permeability Barrier. Biochemical and Biophysical Research Communication, 445(1):30-35.

Montero, D. Walter, G., Stehouwer, C., Houben, A., Beckman, J., and Vinet, A. (2013). Effect of Antioxidant Vitamin Supplementation on Endothelial Function in Type 2 Diabetes Mellitus: a Systematic Review and Meta-analysis of Randomized Controlled Trials. Obesity Review, 15(2):107-116.

National Cholesterol Education Program (NCEP) (2001). Expert Panel on Detection, Evaluation and Treatment of High Blood Cholesterol in Adults, an Executive Summary of the Third Report of NCEP. The Journal of the American Medical Association, 285: 2486-2497

National Institute for health and Care Excellence (2004). Type 1 Diabetes Diagnosis and Treatment of Type 1 Diabetes in Children and Young People: (www.nice.org.uk/pdf/type1diabetes).

Njagi, J.M. (2006). Hypoglycaemic Effects of some Kenyan Plants used Traditionally in the Management of Diabetes Mellitus in Gachoka Division, Mbeere District, Msc thesis, Kenyatta University, Kenya.

Nuttall, F.Q. (1993). Dietary Fiber in the Management of Diabetes. Diabetes, 42: 503- 508.

Olsen, S. F., Halldorsson, T. I., Willett, W. C. (2007). Milk Consumption During Pregnancy is Associated with
Increased Infant Size at Birth: Prospective Cohort Study. American Journal of Clinical Nutrition, 86 (4), 1104-1110.

Overby, N.C., Flaaten, V., and Veierød, M.B. (2007). Children and Adolescents with Type 1 Diabetes Eat a More Atherosclerosis-prone Diet than Healthy Control Subjects. Diabetologia, 50: 307-316.

Paolisso, G., Balbi, V., Volpe, C., Varricchio, G., Gambardella, A., and Saccomanno, F. (1995) Metabolic Benefits Deriving from Chronic Vitamin C Supplementation in Aged Noninsulin Dependent Diabetics. Journal of the American College of Nutrition, 14(4):387-392.

Piero, M.N. (2006). Hypoglycaemic Effects of some Kenyan Plants Traditionally used in Management of Diabetes Mellitus in Eastern Province, Msc thesis, Kenyatta University.

Piero, M.N., Nzaro, G.M., and Njagi, J.M. (2014). Diabetes Mellitus: A Devastating Metabolic Disorder. Asian Journal of Biomedical and Pharmaceutical Sciences, 04 (40): 1-7.

Rabbani, N. and Thornalley, P. J. (2011). Emerging Role of Thiamine Therapy for Prevention and Treatment of Earlystage Diabetic Nephropathy. Diabetes, Obesity and Metabolism, 13:577-683.

Reader, D., Splott, P., and Gunderson, E. P. (2006). Impact of Gestational Diabetes Mellitus Nutrition Practice Guidelines Implemented by Registered Dietitians on Pregnancy Outcomes. Journal of American Dietetic Association, 106(9): 1426-1423.

Reece, E. A. (2008). Perspectives on Obesity, Pregnancy and Birth Outcomes in the United States: The Scope of the Problem. American Journal of Obstetrics and Gynecology, 198(1): 23-27.

Rita, S. (2015). Micronutrients.Pediatric Child Health (oxford). Retrieved on November, 2016.

Shaw, J.E., Sicree, R.A., and Zimmet, P.Z. (2010). Global Estimates of the Prevalence of Diabetes for 2010 and 2030. Diabetes Research and Clinical Practice, 87:4-14. 
Sicree, R., Shaw, J., and Zimmet, P. (2006).The Global Burden.Diabetes and Impaired Glucose Tolerance.Prevalence and Projections. International Diabetes Federation, pp. 16-103.

Smart, C., Aslander-van, V.E., and Waldron, S. (2009). Nutritional Management in Children and Adolescents with Diabetes. Pediatric Diabetes, 10 (Suppl. 12): 100-117.

Stern, N.P., Mann, J., Bennett, P.H., Temple, N., Zimmet, P., Tuomilehto, J., Lindstram, J., and Louheranta, A. (2004). Diet, Nutrition and the Prevention of Type 2 Diabetes. Public Health Nutrition, 7(1A):147-165

Taiwo, A.O. (2010). Dietary Intake and Management of Selected Diabetic Patients in Abeokuta. A B.Sc. Project Submitted to the Department of Nutrition and Dietetics, University of Agriculture, Abeokuta.

Tang, W., Martin, K., and Hwa, J. (2012).Aldose Reductase, Oxidative Stress and Diabeties Mellitus. Frontiers in Pharmacology, 3:87

The Diabetes Control and Complications Trial Research Group (1993).The Effect of Intensive Treatment of Diabetes on the Development and Progression of Long-term Complications in Insulin-dependent Diabetes Mellitus. The New England Journal of Medicine, 329:977-986.

Thornalley, P., Babaei, R., Al ali, H., Rabbani, N., Antonysunil, A., Larkin, J., Ahmed, A., Rayman, G., and Bodmer, C. (2007). High Prevalence of Low Plasma Thiamine Concentration in Diabetes Linked to a Marker of Vascular Disease. Diabetologia, 50:2164-2170.

Tuomilehto, J., Lindstr\&m, J., Eriksson, J.G. (2001). Prevention of Type 2 Diabetes Mellitus by Changes in Lifestyle among Subjects with Impaired Glucose Tolerance. The New England Journal of Medicine, 344 (18): 1343-50.

UK Prospective Diabetes Study (UKPDS) Group (1998). Intensive Blood Glucose Control with Sulphonylureas or Insulin Compared with Conventional Treatment and Risk of Complications in Patients with Type 2 Diabetes (UKPDS 33). Lancet, 352:837-853.
Umar, S.I., M. Ndako, A.A. Jigam, S.F. Adefolalu, G.F. Ibikunle and B. Lawal, (2019). Anti-plasmodial, anti-inflammatory, anti-nociceptive and safety profile of Maytenus senegalensis root bark extract on hepato-renal integrity in experimental animals. Comp. Clin. Pathol., 28: 1571-1579.

Vasudevan, D.M., Sreekumari, S., and Kannan, V. (2011). Textbook of Biochemistry for Medical Student (6 ${ }^{\text {thed.). }}$ pp 287.

Vessby, B., Uusitupa, M., Hermansen, K., Riccardi, G., Rivellese, A., Tapsell, L.C., Nalsen, C., Berglund, I., Louheranta, A., Rasmussen, B.M., Calvert, G.D., Maffettone, A., Pedersen, E., Gustafsson, I.B., and Storlien, L.H. (2001). Substituting Dietary Saturated Fat for Monounsaturated Fat Impairs Insulin Sensitivity in Healthy Men and Women. Diabetologia, 44:312-9

Virtanen, S.M., Virta-Autio, P., Rasanen, L., and Akerblom, H.K. (2001): Changes in Food Habits in Families with a Newly Diagnosed Child with Type 1 Diabetes Mellitus. Journal of Pediatric Endocrinology and Metabolism, 14: 627636.

Votey, S.R., and Peters, A.L. (2004). Diabetes Mellitus Type 2. A Review. Accessed September, 2016. (www.emedicine.com/emerg/topic133.htm)

Whitney, E., and Sharon R.R. (2013). Understanding Nutrition (13 ed.). Wadsworth, Cengage Learning. pp. 667-670.

Whitney, E., and Sharon, R.R. (2005). Understanding Nutrition, 10th edition. pp. 6

Williams, C.L. (2006). Dietary Fiber in Childhood. Journal of Pediatric, 149(5S): S121-S130.

Wylie-Rosett, J., Segal-Isaacson, C.J., and Segal-Isaacson, A. (2004). Carbohydrates and Increases on Obesity: Does the Type of Carbohydrate Make a Difference? Obesity Research and clinical practice, 12:124S-129S.

Ylonen, K., Alfathan, G., Groop, L., Saloranta, C., Aro, A., and Virtanen, S. (2003). Dietary Intake and Plasma Concentrations of Carotenoids and Tocopherol in Relation to Glucose Metabolism in Subjects at High Risk of Type 2

Citations: Muhammed D, Adebiyi YH, Odey BO, Ibrahim J, Hassan ON, Ugwunnaji PI, and Berinyuy E.B. (2021). Nutritional Management of Diabetes Mellitus: An appraisal of the role of Medicinal plants. AROC in Natural Product Research. 01(01), 001-027 
Diabetes: The Botnia Dietary Study. American Journal of Clinical Nutrition, 77: 1434-1441

Yusuf, A.A., B. Lawal, A.N. Abubakar, E.B. Berinyuy and Y.O. Omonije et al., (2018). In-vitro antioxidants, antimicrobial and toxicological evaluation of Nigerian Zingiber officinale. Clin. Phytosci., Vol. 4., No. 1. 10.1186/s40816-018-0070-2.

Yusuf, A.A., B. Lawal, M.A. Yusuf, A.O. Adejoke, F.H. Raji and D.L. Wenawo, (2018). Free radical scavenging, antimicrobial activities and effect of sub-acute exposure to Nigerian Xylopia aethiopica seed extract on liver and kidney functional indices of albino rat. Iran. J. Toxicol., 12: 51-58.

Yusuf, A.A., B. Lawal, S. Sani, R. Garba, B.A. Mohammed, D.B. Oshevire and D.A. Adesina, (2020). Pharmacological activities of Azanza garckeana (goron tula) grown in Nigeria. Clin. Phytosci., 10.1186/s40816-020-00173-0.

Yusuf, S., Dagenais, G., and Pogue, J. (2000). Vitamin E Supplementation and Cardiovascular Events in High Risk Patients. Heart Outcomes Prevention Evaluation Study Investigators. The New England Journal of Medicine, 342:154-160.

Zipitis C. S. and Akobeng A. K. (2008). Vitamin D Supplementation in Early Childhood and Risk of Type 1 Diabetes: A Systematic Review and Meta-analysis. Archives of Disease in Childhood. 93:512-517. 